ARTICLE OPEN

Check for updates

\title{
Near-field corrosion interactions between glass and corrosion resistant alloys
}

\author{
Xiaolei Guo $\mathbb{D}^{1 凶}{ }^{4}$, Stephane Gin $\mathbb{D}^{2}$, Hongshen Liu $\mathbb{D}^{3}$, Dien $\mathrm{Ngo}^{3}$, Jiawei Luo ${ }^{3}$, Seong H. Kim ${ }^{3}$, Chandi Mohanty ${ }^{1}$, John D. Vienna ${ }^{4}$, \\ Joseph V. Ryan ${ }^{4}$ and Gerald S. Frankel $\mathbb{D}^{1}$
}

This study explores the corrosion interactions between model nuclear waste glass materials and corrosion resistant alloys, under accelerated conditions that simulate the near field of a nuclear waste repository. The interactions between the corrosion of stainless steel (SS) 316, alloy G30, or alloy 625 , and international simple glass or soda-lime silica glass are systematically studied. The dissimilar materials were exposed in close proximity to each other in different electrolytes at $90^{\circ} \mathrm{C}$. After exposure, the glass surface exposed near metals showed different regimes of corrosion, with distinct surface morphologies and chemistries that were likely affected by the local environment created by the localized corrosion of metals. Surface and solution analyses showed that the corrosion rate of glass was enhanced by the presence of metals. Infrared spectroscopy data suggested the local build-up of stresses in the contact area of glass, which may lead to the mechanical instability of the glass alteration layer. On the other hand, the effect of glass on metal corrosion is strongly dependent on the leaching solution. In electrolytes containing abundant aggressive anions such as $\mathrm{Cl}^{-}$, glass seems to suppress the localized corrosion of SS by the precipitation of a Si-rich surface film that protects the SS substrate from solutions. However, in less aggressive electrolytes, the corrosion rate of SS was increased by the presence of glass corrosion products. Overall, our study showed that the hidden and localized damage on glass in contact with metals may enhance the release rate of glass components compared to typical uniform glass corrosion.

npj Materials Degradation (2020)4:10; https://doi.org/10.1038/s41529-020-0114-1

\section{INTRODUCTION}

The high-level nuclear waste (HLW) existing as the legacy of defense applications and other by-products of spent nuclear fuel reprocessing will be melted into borosilicate glass, and then cast into stainless steel (SS) canisters ${ }^{1}$. These canisters will be enclosed within waste packages and then emplaced in a mined underground geologic repository, which is the approach planned by most countries with such waste ${ }^{2}$. In the U.S. program, the current waste package design includes glass being cast into SS 304 canisters then encased in a SS 316 inner shell and an Alloy 22 outer shell ${ }^{3,4}$. The repository system is designed to isolate the highly radioactive waste from humans for hundreds of thousands of years ${ }^{4}$. However, after an extremely long time of exposure, underground water might eventually break down the metallic structures by localized corrosion ${ }^{5}$. Alloy 22 is an extremely corrosion resistant metal alloy, so any environment that could corrode Alloy 22 would also easily penetrate the SS structures within the canister and allow the corrosive environments to attack the encapsulated glass waste forms, leading to the release of radionuclides. Crevice corrosion ${ }^{6-8}$ may also be triggered once aqueous environment exists at the interface between the SS canister and the nuclear waste glass, which may create a series of issues.

The effect of Fe and Fe oxide/oxyhydroxide on the corrosion of nuclear waste glass has been investigated by several studies ${ }^{9-15}$. The first work was published by McVay et al. ${ }^{9}$, who altered PNL 76-68 borosilicate glass and carbon steel together at $90^{\circ} \mathrm{C}$ in various aerated solutions, including deionized water, tuff groundwater, and basalt groundwater. They reported that the corrosion rates of glass and steel were both enhanced due to the synergistic reactions of the two materials. The authors attributed the enhanced corrosion rate to the formation of Fe-silicate precipitates, which suppressed the saturation of leaching solution and caused a delay in the onset of the residual rate regime. Burger et al. altered SON68 glass in the presence of pure iron powder in an anoxic clayey environment at $50{ }^{\circ} \mathrm{C}$ for 2 years ${ }^{10}$. They found that metallic Fe powders only influenced the immediate vicinity of the $\mathrm{Fe}$ and glass interface, where Fe-silicates were observed. Nanosized Fe-silicates precipitates were also found within the pores of the gel. It is believed that iron corrosion products, primarily $\mathrm{Fe}_{2} \mathrm{O}_{3}, \mathrm{Fe}_{3} \mathrm{O}_{4}$, and $\mathrm{FeOOH}$ will also affect glass durability in the near field. Werme et al. reported a deleterious effect of $\mathrm{Fe}_{3} \mathrm{O}_{4}$ or $\mathrm{FeOOH}$ on the durability of nuclear waste glass, with $\mathrm{FeOOH}$ exhibiting a stronger effect ${ }^{11}$. The extent of glass corrosion was found to increase as the amount of $\mathrm{Fe}_{3} \mathrm{O}_{4}$ increased. In addition to the Fe-silicate formation mechanism, the authors proposed that the adsorption of $\mathrm{Si}$ on the surface of $\mathrm{Fe}_{3} \mathrm{O}_{4}$ or $\mathrm{FeOOH}$ could also play a role, because the acceleration of glass corrosion was diminished when all the adsorption sites on $\mathrm{Fe}_{3} \mathrm{O}_{4}$ or $\mathrm{FeOOH}$ were completely occupied. We recently described the corrosion interactions between a more realistic SS canister material and a model nuclear waste glass, international simple glass (ISG), under accelerated conditions by pressing the two materials against each other and immersing the assembly in $\mathrm{NaCl}$ solution at $90^{\circ} \mathrm{C}^{16}$ In addition to the precipitation of Fe-silicates, new mechanisms were revealed. The crevice corrosion of SS resulted in an aggressive acidic environment that could significantly enhance the corrosion of ISG present nearby. A continuous film was observed across the entire SS surface, consisting of elements that originated from SS and ISG corrosion. Meanwhile,

\footnotetext{
${ }^{1}$ Department of Materials Science and Engineering, Ohio State University, Columbus, OH 43210, USA. ${ }^{2}$ CEA, DEN, DE2D, Université de Montpellier, Marcoule, France. ${ }^{3}$ Department of Chemical Engineering and Materials Research Institute, Pennsylvania State University, University Park, PA 16802, USA. ${ }^{4}$ Energy and Environment Directorate, Pacific Northwest National Laboratory, Richland, WA 99352, USA. ${ }^{\circledR}$ email: guo.237@buckeyemail.osu.edu
} 
precipitation of Si-bearing minerals was identified, which was likely assisted by the SS cathodic reactions. The precipitation of the Si-bearing surface film and minerals could strongly consume $\mathrm{Si}$ from the solution, which may eventually lead to the accelerated glass corrosion that is known as stage III corrosion ${ }^{17,18}$.

This study aims to further explore the corrosion interactions between two model glass materials (soda-lime silica glass (SLSG) and ISG and three corrosion resistant alloys (SS, alloy G30, and alloy 625) to develop a fundamental understanding of the corrosion interactions between dissimilar materials in $\mathrm{Cl}^{-}$ions containing solutions. SLSG is a prevalent type of glass that has vast applications in our daily life, for example tableware and windowpanes. Due to its simplicity in chemistry compared to nuclear waste glass, it was applied in this work. The initial study was then extended to the more corrosion resistant glass ISG ${ }^{19,20}$, which has been investigated world-wide as a model nuclear waste glass. Alloy G30 and alloy 625 were selected due to their superior corrosion resistance compared to $\mathrm{SS}^{21}$. We have shown that $\mathrm{SS}$ crevice corrosion could accelerate the degradation of nearby $\mathrm{ISG}^{16}$, so it would be of interest to explore the corrosion interactions between the model glass and these more corrosion resistant alloys.

\section{RESULTS}

\section{Corrosion of soda-lime silica glass}

To simulate the corrosion of metal canisters and nuclear waste glass under accelerated conditions, different materials were pressed against each other and corroded in $0.6 \mathrm{M} \mathrm{NaCl}$ solution or DI water at $90^{\circ} \mathrm{C}$. Although the initial ionic strength may be lower in the actual repository conditions, $\mathrm{Cl}^{-}$and $\mathrm{Na}^{+}$ions are likely to be enriched at the material interface during corrosion ${ }^{16}$. The complete experimental groups are listed in Table 1. For simplicity, the terminology $A\left(+B_{\text {Solution }}\right)$ is used throughout this article to describe the sample assemblies. For example, SS $\left(+\mathrm{SLSG}_{\mathrm{NaCl}}\right)$ means an SS sample that was pressed against SLSG, with exposure in $\mathrm{NaCl}$ solution. As shown in Fig. 1a, after 14 days of corrosion, a band pattern formed on $\mathrm{SS}\left(+\mathrm{SLSG}_{\mathrm{NaCl}}\right)$, located near the boundary of the SS and SLSG contact area. These corrosion patterns are characteristics of the metal crevice corrosion, which is commonly observed on passive metals ${ }^{6}$. During metal crevice corrosion, damage usually initiates within the crevice at a particular distance from the crevice mouth area due to

Table 1. List of experimental groups and testing conditions for SS and glass corrosion.

\begin{tabular}{lllll}
\hline Sample ID & Materials & Solution & Temperature & Duration \\
\hline SLSG-SS-NaCl & SLSG + SS 316 & $0.6 \mathrm{M} \mathrm{NaCl}$ & $90^{\circ} \mathrm{C}$ & 14 Days \\
SLSG-PTFE- & SLSG + PTFE & $0.6 \mathrm{M} \mathrm{NaCl}$ & $90^{\circ} \mathrm{C}$ & 14 Days \\
NaCl & & & & \\
SLSG-SS-DIW & SLSG + SS 316 & DI water & $90^{\circ} \mathrm{C}$ & 14 Days \\
SLSG-PTFE- & SLSG + PTFE & DI water & $90^{\circ} \mathrm{C}$ & 14 Days \\
DIW & & & & \\
SLSG-G30- & SLSG + & $0.6 \mathrm{M} \mathrm{NaCl}$ & $90^{\circ} \mathrm{C}$ & 14 Days \\
NaCl & Alloy G30 & & & \\
SLSG-A625- & SLSG + A625 & $0.6 \mathrm{M} \mathrm{NaCl}$ & $90^{\circ} \mathrm{C}$ & 14 Days \\
NaCl & & & & \\
ISG-SS-NaCl & ISG + SS 316 & $0.6 \mathrm{M} \mathrm{NaCl}$ & $90^{\circ} \mathrm{C}$ & 30 Days \\
SS-PTFE-NaCl & SS $316+$ PTFE & $0.6 \mathrm{M} \mathrm{NaCl} 90^{\circ} \mathrm{C}$ & 30 Days \\
ISG-PTFE-NaCl & ISG + PTFE & $0.6 \mathrm{M} \mathrm{NaCl}$ & $90^{\circ} \mathrm{C}$ & 30 Days \\
ISG-SS-DIW & ISG + SS 316 & DI water & $90^{\circ} \mathrm{C}$ & 30 Days \\
SS-PTFE-DIW & SS $316+$ PTFE & DI water & $90^{\circ} \mathrm{C}$ & 30 Days \\
ISG-PTFE-DIW & ISG + PTFE & DI water & $90^{\circ} \mathrm{C}$ & 30 Days \\
\hline
\end{tabular}

the ohmic potential drop. In this region, the protective film breaks down and metal cations, protons, and aggressive anions such as chlorides accumulate, leading to highly aggressive environment that results in self-acceleration of the localized metal corrosion ${ }^{6-8}$. As a result of this spontaneous change in local chemistry, crevice corrosion is one of the most detrimental forms of metal corrosion, particularly for fabricated structures. Interestingly, similar patterns were also obtained on the SLSG $\left(+\mathrm{SS}_{\mathrm{NaCl}}\right)$ surface (Fig. $\left.1 \mathrm{a}^{\prime}\right)$, where the corrosion was localized along the edge of the contact area, while the center of the crevice region was less corroded according to visual observation. This general observation was also verified by both solution and local surface analyses as described in the following sections. Note that two bands were observed on the $\mathrm{SLSG}\left(+\mathrm{SS}_{\mathrm{NaCl}}\right)$ : (i) the outer band delineates the boundary of the SS/SLSG contact area, which could be attributed to the alkaline attack caused by the cathodic oxygen reduction reaction (ORR) on the SS coupon surface surrounding the crevice edge, (ii) an inner band that was located a few millimeters deeper from the boundary, which was likely due to the acidic attack induced by SS crevice corrosion. An enlarged view of Fig. 1a' shows that the inner band region on the glass was more corroded, which was accompanied by partial removal of the alteration layer that probably occurred during sample drying. It has been well documented that glass corrosion rate in diluted solutions is enhanced by several orders of magnitude under both acidic and alkaline conditions relative to neutral conditions ${ }^{22,23}$. Recent studies showed that this statement is still valid when the glass corrosion reaches a steady state regime (stage II) where the solution is saturated with silica, although the rate-limiting mechanisms are likely not the same for the two regimes ${ }^{24}$. Therefore, the corrosion of SS in close proximity to glass could significantly enhance glass corrosion at both the anode and the cathode sites on the SS. It has been known that the sample surface area to solution volume $(\mathrm{S} / \mathrm{V})$ ratio can strongly affect glass corrosion $^{25}$, so a control experiment was carried out by replacing the SS with PTFE (Fig. 1b), which would create a similar crevice with comparative $S / V$ but not be reactive. As shown in Fig. $1 b^{\prime}$, only a random corrosion morphology was observed on the SLSG $\left(+\mathrm{PTFE}_{\mathrm{NaCl}}\right)$. Apparently, the high S/V ratio cannot fully explain the unique corrosion morphology observed in Fig. 1a, suggesting that SS indeed played an important role.

When DI water was used as the electrolyte, no clear crevice corrosion pattern was observed on $\mathrm{SS}\left(+\mathrm{SLSG}_{\mathrm{DIw}}\right.$ ) (Fig. 1c) but drastically different corrosion morphologies were observed on $\mathrm{SLSG}\left(+\mathrm{SS}_{\mathrm{DIw}}\right)$. As shown in Fig. $1 \mathrm{c}^{\prime}$, uniform corrosion was observed within the center of the contact region. Note that no chloride ions were present in the solution to break down the passive film of SS, so it is unlikely that crevice corrosion could occur here. However, a low amount of $\mathrm{Fe}^{2+}$ or $\mathrm{Fe}^{3+}$ ions could still exist in the occluded crevice environment due to the passive dissolution of SS, which seemed to influence the corrosion of SLSG within the center of the crevice. Interestingly, the size of the visibly discernable corrosion area on the SLSG surface was much smaller than the actual contact area, which may also be associated with mass transport from the edge region. However, different than crevice corrosion, the uniform passive dissolution on the SS in DI water resulted in uniform attack of the glass. For SLSG that was in contact with PTFE in DI water (Figs. $1 d^{-}-d^{\prime}$ ), no visible damage was observed on the SLSG surface, which further indicates that the morphology observed in Fig. $1 c^{\prime}$ could not be simply attributed to the high S/N ratio. Comparing Fig. $1 b^{\prime}$ with Fig. $1 d^{\prime}$, it may be concluded that $\mathrm{NaCl}$ also enhances the corrosion of SLSG.

Similar crevice corrosion phenomena were observed when the SS was replaced with more corrosion resistant alloys such as G30 (Fig. 1e-g) and alloy 625 (hereafter referred to as A625) (Fig. 1h, j). After 14 days of corrosion, pitting damage was clearly identified at the crevice mouth of both alloys. Meanwhile, localized corrosion was also observed at the crevice mouth of SLSG, while the center 


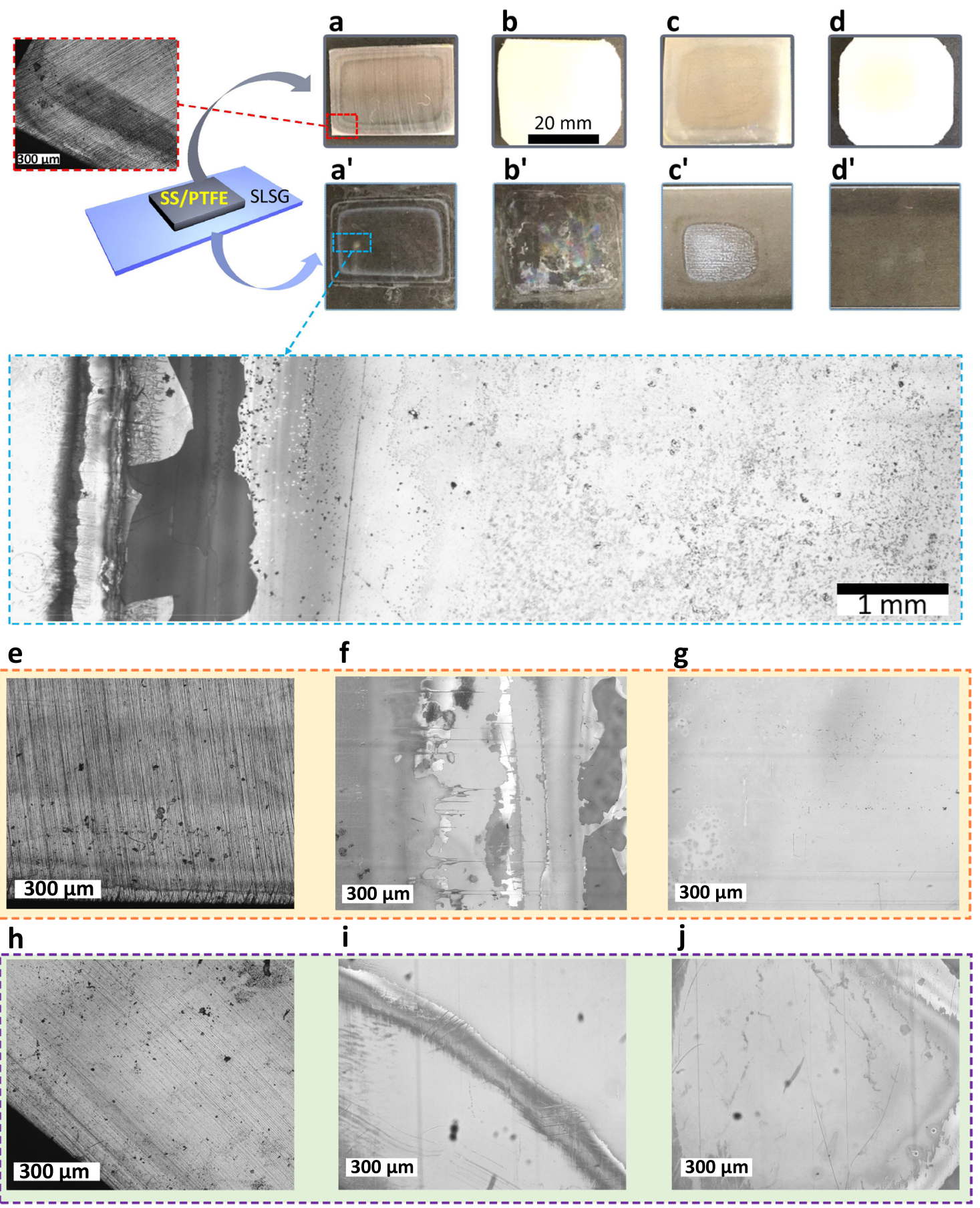

Fig. 1 Surface morphologies of different samples after 14 days of corrosion at $90^{\circ} \mathrm{C}$. a SLSG \& SS corroded in $0.6 \mathrm{M}$ NaCl, b SLSG \& PTFE corroded in $0.6 \mathrm{M} \mathrm{NaCl}$, (c) SLSG \& SS corroded in DI water, d SLSG \& PTFE corroded in DI water. e Crevice mouth area of G30(+SLSG $\mathrm{NaCl})$.

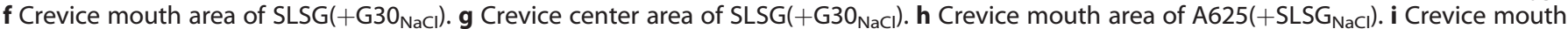
area of SLSG $\left(+A 625_{\mathrm{NaCl}}\right)$. $\mathbf{j}$ Crevice center area of SLSG(+A625 $\left.5_{\mathrm{NaCl}}\right)$.

region appeared less altered. This suggests that the influence of metal crevice corrosion on glass is likely universal in these solution conditions and could be difficult to avoid even with extremely corrosion resistant alloys.

Specular reflectance infrared (SR-IR) spectroscopy was used to explore the changes of silicate networks on the corroded SLSG $\left(+\mathrm{SS}_{\mathrm{NaCl}}\right)$ surface. The spectra were collected from five different locations. The results are shown in Fig. $2 a$. Figure $2 b$ is a macrograph of SLSG $\left(+\mathrm{SS}_{\mathrm{NaCl}}\right)$ showing the analyzed locations. On the pristine SLSG, three major peaks were identified. The peak observed at $1057 \mathrm{~cm}^{-1}$ is attributed to the asymmetric stretch

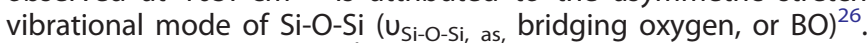
The shoulder at $\sim 942 \mathrm{~cm}^{-1}$ is associated with stretching vibration of the $\mathrm{Si}-\mathrm{O}^{-}$(nonbridging oxygen, or $\mathrm{NBO}$ ) group and $\mathrm{Si}-\mathrm{OH}$ in the glass $^{26}$. The peak at $762 \mathrm{~cm}^{-1}$ corresponds to symmetric vibration of $\mathrm{Si}-\mathrm{O}-\mathrm{Si}\left(\left(\mathrm{U}_{\mathrm{Si}-\mathrm{O}-\mathrm{Si}}, \mathrm{s}, \mathrm{BO}\right)^{26}\right.$. The corroded SLSG shows some distinct changes in different locations indicative of chemical degradation. In the crevice mouth area, which is located between the inner and outer bands, the highest spectral intensity for the asymmetric vibration peak of $\mathrm{Si}-\mathrm{O}-\mathrm{Si}$ was markedly shifted to 
a

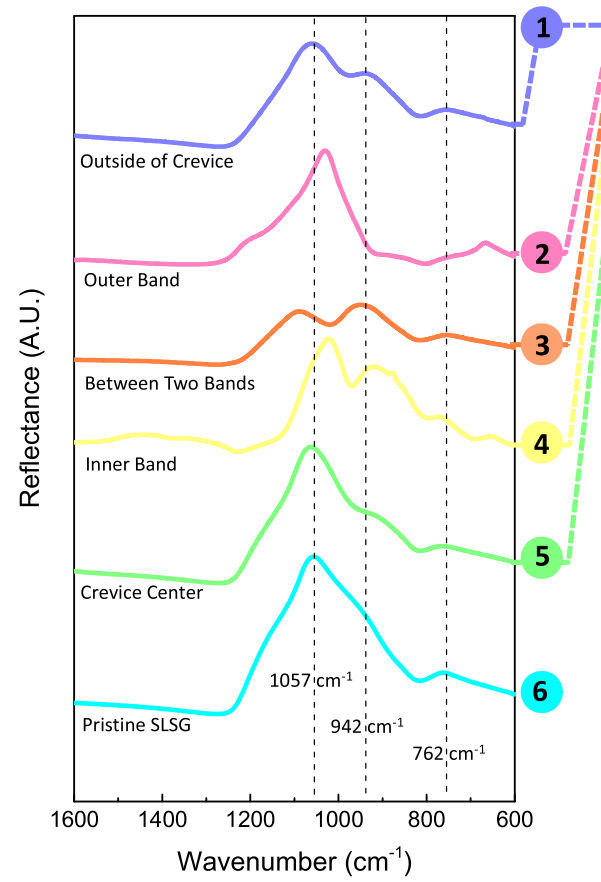

b

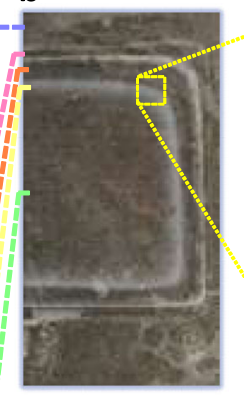

c

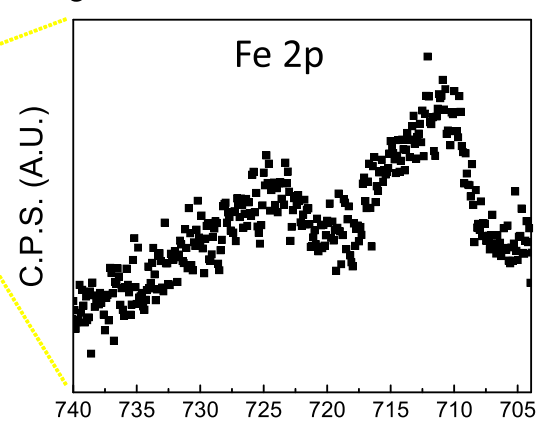

d $\widehat{\bar{ก}} 0.25 \quad \mathrm{BE}(\mathrm{eV})$

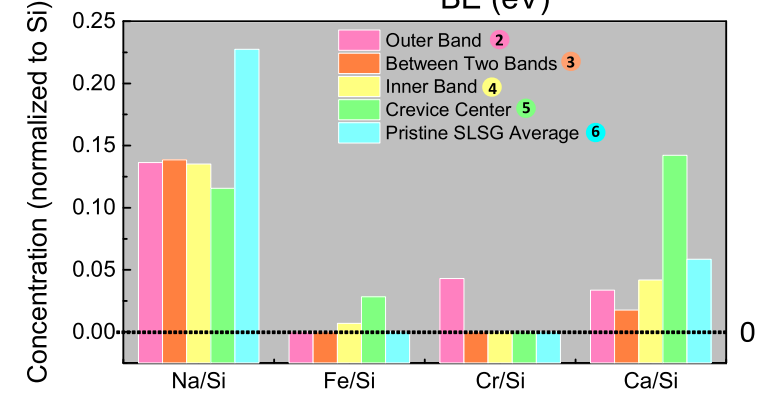

Fig. 2 Surface analysis of SLSG( + SS $_{\mathrm{Nacl}}$ ). a SR-IR spectra collected from different regions. b Macrograph of SLSG(+SS $\left.\mathrm{NaCl}\right)$ showing the analyzed locations. c XPS spectra collected from the inner band region. $\mathbf{d}$ Chemical composition of different regions quantified by XPS.

$1100 \mathrm{~cm}^{-1}$, which is close to that of fused quartz ${ }^{27}\left(1120 \mathrm{~cm}^{-1}\right)$. This is indicative of a leaching process (partial dissolution of alkali followed by slow silanol condensation) that is likely associated with acidic attack. During this process, the $\mathrm{Na}^{+}$ions are exchanged with protons originating from water dissociation, which can be accompanied by the shortening of $\mathrm{Si}-\mathrm{O}$ bond length, causing the build-up of tensile stress in the glass network in the crevice mouth area ${ }^{28}$. Meanwhile, the shoulder peak at $\sim 942 \mathrm{~cm}^{-1}$ from the pristine SLSG became more evident, which may be attributed to the conversion of $\mathrm{BO}$ to $\mathrm{NBO}$ or $\mathrm{Si}-\mathrm{OH}$ groups after leaching ${ }^{26}$. The spectra are similar for the crevice center and the area outside of crevice, which show only slight shift of the 1057 and $762 \mathrm{~cm}^{-1}$ peaks, while the $\sim 942 \mathrm{~cm}^{-1}$ peak also became more evident. These two spectra are also close to that of pristine SLSG, suggesting that the two areas are less altered compared to the crevice mouth region. The spectra collected from the two stained bands regions showed clear red shift of the 1057 and $762 \mathrm{~cm}^{-1}$ peaks. If this is caused by the ingress of metal cations (such as $\mathrm{Fe}^{2+}, \mathrm{Fe}^{3+}$, or $\mathrm{Cr}^{3+}$ ) with different sizes into the Si network, it could also generate internal stress in the alteration layer and affect the $\mathrm{Si}-\mathrm{O}$ stretch band position ${ }^{28,29}$. This assumption was supported by the observation of new peaks near $650-660 \mathrm{~cm}^{-1}$, which could be attributed to the stretching vibration of $\mathrm{Fe}-\mathrm{O}^{30,31} \mathrm{or} \mathrm{Cr}-\mathrm{O}^{32}$. The mismatch of local stress between different regions may explain the rupture of the gel layer observed in the crevice mouth area shown in Fig. 1 $a^{\prime}$.

The presence of metal cations $\left(\mathrm{Fe}^{2+}, \mathrm{Fe}^{3+}\right.$, or $\left.\mathrm{Cr}^{3+}\right)$ on SLSG $\left(+\mathrm{SS}_{\mathrm{NaCl}}\right)$ was further validated by $\mathrm{X}$-ray photoelectron spectroscopy (XPS). As shown in Fig. 2c, it is clear that $\mathrm{Fe}^{2+}$ or $\mathrm{Fe}^{3+}$ does exist in the inner band region. However, the low resolution (due to low concentration) made the identification of valance state difficult. The composition of SLSG $\left(+\mathrm{SS}_{\mathrm{NaCl}}\right)$ at the abovementioned locations was also quantified by XPS (Fig. 2d). Depletion of $\mathrm{Na}$ is apparent across the entire surface and varies slightly with location. Despite the high concentration of $\mathrm{Na}^{+}$in the medium, the partial loss of $\mathrm{Na}^{+}$ions in the altered layer strongly suggests that ions exchange occurred between $\mathrm{Na}^{+}$from the glass and protons generated by water dissociation. Depletion of Ca was observed for all locations except for the crevice center, where Ca was significantly enriched (more than a factor of 2). This further supports the notion that the crevice corrosion primarily occurred near the crevice mouth region, which led to the local acidification in that area. Fe was identified at the inner band area and the crevice center, which was more evident in the crevice center. The presence of Fe in the inner band is consistent with SR-IR results. However, SR-IR results suggest that Fe is absent within the crevice center, which does not agree with the XPS result. This indicates that Fe may exist as a precipitated thin layer in the crevice center, while $\mathrm{Fe}^{2+}$ or $\mathrm{Fe}^{3+}$ ions were incorporated into Si network in the inner band region. No Fe was found in the outer band region. Instead, a strong $\mathrm{Cr}$ signal was detected in this region, which again suggests the ingress of $\mathrm{Cr}^{3+}$ ions into the altered glass network, consistent with the SR-IR results.

\section{Corrosion of ISG}

Corrosion morphology. It is evident that SS has substantial effects on the corrosion of SLSG. However, most nuclear waste glass has a more complicated chemistry and the corrosion mechanism may be different than SLSG. Therefore, a model nuclear waste glass, ISG $^{19}$, was studied. The corrosion behavior of this SS + ISG system has been partially described in a previous paper ${ }^{16}$. More results are provided in this study. As shown in Fig. 3a, crevice corrosion characteristics were also observed on ISG $\left(+\mathrm{SS}_{\mathrm{NaCl}}\right)$ after 30 days of exposure at $90^{\circ} \mathrm{C}$. An obvious band corrosion pattern can be seen near the crevice mouth area, while the center region was less corroded. The morphology was similar to what was observed on SLSG $\left(+\mathrm{SS}_{\mathrm{NaCl}}\right)$ as shown in Fig. $1 \mathrm{a}^{\prime}$. Control experiments were conducted by pressing ISG against SS or PTFE, followed by immersion in $0.6 \mathrm{M} \mathrm{NaCl}$ or DI water at $90^{\circ} \mathrm{C}$ for 30 days. The surface morphologies of ISG $\left(+\mathrm{SS}_{\mathrm{NaCl}}\right)$, ISG $\left(+\mathrm{TFE}_{\mathrm{NaCl}}\right), \mathrm{ISG}\left(+\mathrm{SS}_{\mathrm{DIW}}\right)$, and $\mathrm{ISG}\left(+\mathrm{PTFE}_{\mathrm{DIW}}\right)$ are shown in Fig. $3 \mathrm{~b}-\mathrm{e}$, respectively. It is evident that the crevice corrosion characteristics are only present on ISG $\left(+\mathrm{SS}_{\mathrm{NaCl}}\right)$, but not on any other samples. The morphologies are consistent with what was observed on SLSG corroded under similar conditions, suggesting that the corrosion interactions 
a ISG(+SS $\left.\mathrm{NaCl}_{1}\right)$, Crevice Mouth

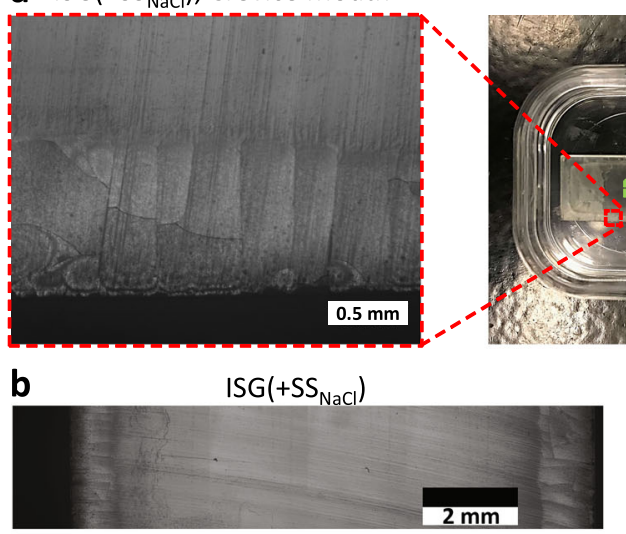

d
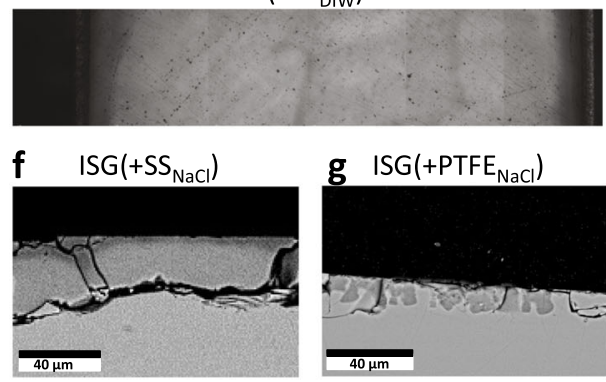

$\operatorname{ISG}\left(+\mathrm{SS}_{\mathrm{NaCl}}\right)$, Center

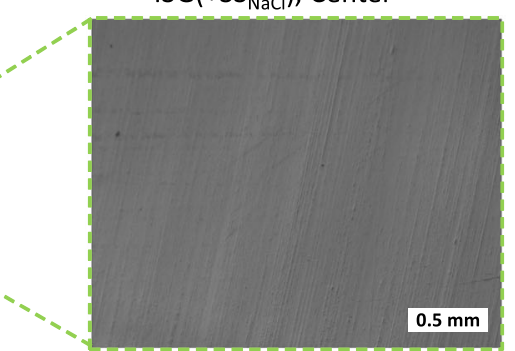

C

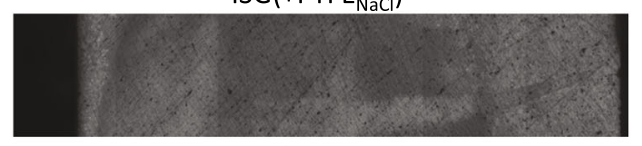

e
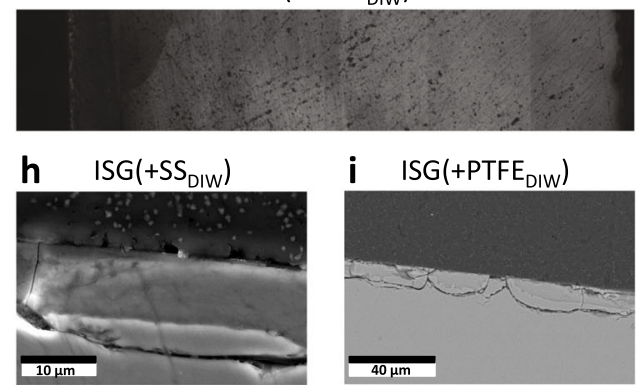

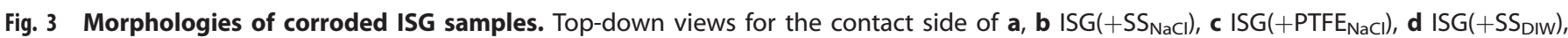

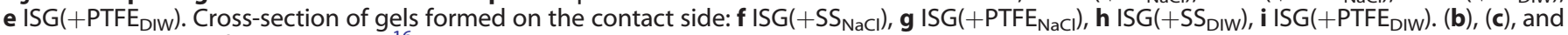
(g) are reproduced from Guo et al. ${ }^{16}$.

between SS and glass are applicable to a broad range of alkalisilicate glasses. During glass corrosion at high $S / N$, mobile elements such as $\mathrm{B}, \mathrm{Na}$, and to a lesser extent $\mathrm{Ca}$ are dissolved into the solution, leaving behind a porous aluminosilicate gel layer $^{33}$. The degree of corrosion is closely correlated to the thickness of the alteration layer ${ }^{34}$. Therefore, the corroded ISG samples were all sectioned to allow observation of the gel layer cross-sections in a scanning electron microscopy (SEM). As shown in Fig. $3 f-i$, the gel layer thickness for ISG $\left(+\mathrm{SS}_{\mathrm{NaCl}}\right)$ is $\sim 25-40 \mu \mathrm{m}$, while the thickness for other samples ranges from 10-15 $\mu \mathrm{m}$, suggesting that more corrosion occurred on ISG(+SS $\left.\mathrm{SaCl}_{\mathrm{NI}}\right)$. Note that the cracks visible in the gel were likely formed during the sample preparation, which is generally the consequence of capillary forces after partial dehydration or the build-up of stresses within the $\mathrm{gel}^{35}$.

\section{Chemical compositions of altered ISG}

The compositional change of the altered ISG was examined by XPS (Fig. 4). For each sample, XPS spectra were obtained from three different locations: the crevice mouth, crevice center, and the noncontact back side. In the previous paper ${ }^{16}$, it was shown that, as a result of SS crevice corrosion, localized acidic attack was observed in the crevice mouth area of the ISG(+SS $\left.\mathrm{NaCl}_{\mathrm{I}}\right)$, where depletion of all major elements except for Si occurred. On the non-contact side of $I S G\left(+S_{\mathrm{NaCl}_{1}}\right), \mathrm{Na}$ and $\mathrm{Ca}$ were both depleted due to ion exchange, while $\mathrm{Zr}$ and Al were slightly enriched. The back side of the ISG was in contact with the PTFE container with a similar S/V ratio as the contact side, so it serves as a good reference. The drastic compositional difference between the two surfaces indicates the crucial effect of SS. In contrast, the corrosion on ISG(+PTFE $\left.\mathrm{NaCl}_{\mathrm{NI}}\right)$ was relatively more uniform than that of ISG $\left(+\mathrm{SS}_{\mathrm{NaCl}}\right)$. In this study, we show that when DI water was used as leaching solution, the effect of SS crevice corrosion was eliminated. As shown in Fig. 4, no Fe was identified on either ISG $\left(+\mathrm{SS}_{\mathrm{DIW}}\right)$ or ISG(+PTFE $\left.\mathrm{DIW}\right)$. Since no $\mathrm{Na}^{+}$was present in the leaching solution, Na was depleted almost completely from the surface of both samples. Enrichment of Ca was observed on the contact and noncontact sides of both samples, but was more evident on the noncontact side. The presence of $\mathrm{Ca}$ in the gel has been known to reduce the reactive diffusion coefficient of water within the gel layer ${ }^{36,37}$, thus enhancing the durability of glass. $\mathrm{Zr}$ was also enriched in the different regions of both ISG(+SS $\left.S_{\text {DIw }}\right)$ and ISG(+PTFE $\left.E_{D I W}\right)$. The enrichment of insoluble $\mathrm{Zr}$ oxides has been observed in other studies ${ }^{38}$, which was believed to impact the residual rate of glass alteration ${ }^{39,40}$. Therefore, the enrichment of $\mathrm{Ca}$ and $\mathrm{Zr}$ on ISG corroded in DI water, along with the depletion of both elements on ISG corroded in $\mathrm{NaCl}$, indicate that $\mathrm{NaCl}$ has an adverse effect on ISG corrosion. The Al concentration is generally similar for $\mathrm{ISG}\left(+\mathrm{SS}_{\mathrm{DIW}}\right)$ and ISG $\left(+\mathrm{PTFE}_{\mathrm{DIW}}\right)$. Overall, the chemical distribution observed on ISG(+SS DIW $\left._{1}\right)$ and ISG(+PTFE $\left.E_{\text {DIW }}\right)$ was relatively similar, suggesting that ISG is not strongly affected by contact with SS in the absence of $\mathrm{Cl}^{-}$ions. This is expected because aggressive anions are critical for the onset of crevice corrosion, by causing the breakdown of the protective passive film. Under disposal-relevant conditions, $\mathrm{Cl}^{-}$will be present in the ground water, although in a much lower concentration ${ }^{41}$. During localized corrosion, $\mathrm{Cl}^{-}$ions will migrate to the occluded anode site to balance the extra charges resulted from metal dissolution, so $\mathrm{Cl}^{-}$ions are likely to be accumulated over time at the interface of the canister and nuclear waste glass. In a typical crevice corrosion event, the local concentration of $\mathrm{Cl}^{-}$can exceed $1 \mathrm{M}^{7}$. Therefore, although the initial $\mathrm{Cl}^{-}$ion concentration may be low $\left(<10 \mathrm{mM}^{42,43}\right)$ under the real repository conditions with no corrosion interaction between the canister and nuclear waste glass, a highly concentrated salt environment may form in the near field of nuclear waste glass, both resulting from and causing accelerated corrosion at the material interface. More studies are required to validate this hypothesis and to further understand the interfacial corrosion between nuclear waste glass and metallic canisters in more realistic ground water environment for a much longer duration, which will lead to improved understanding of the implications for nuclear waste disposal. 

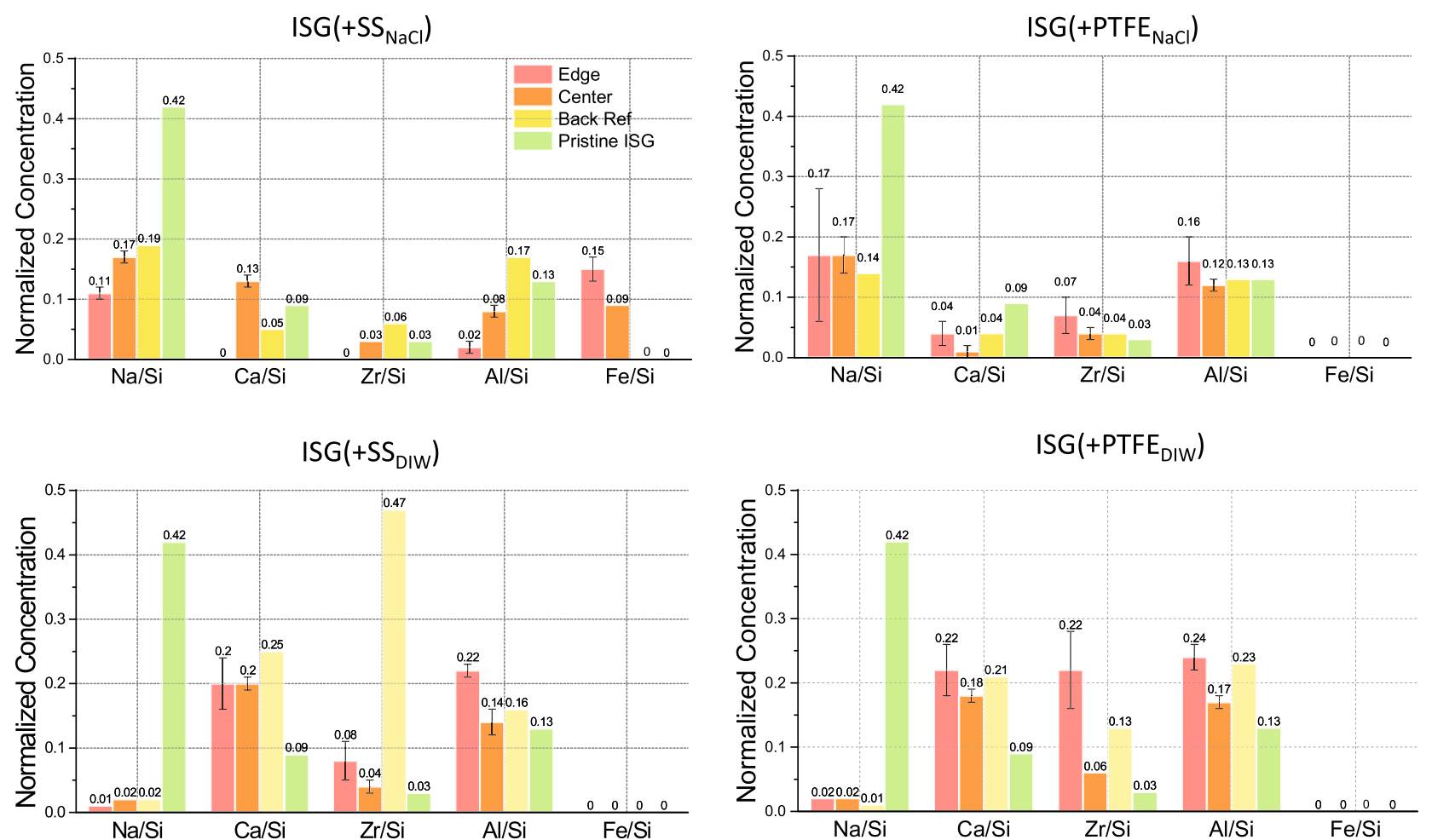

Fig. 4 Chemical composition of corroded ISG obtained by XPS. Data in NaCl adapted from Guo et al. ${ }^{16}$ For back side references ("Back Ref" in the figure), data were acquired from one representative area, so no error bar is presented. Error bars are defined as standard error of the mean.

\section{Solution analysis}

Inductively coupled plasma optical emission spectrometry (ICPOES) was employed to further estimate the gel properties by measuring the concentration of different elements in the bulk leaching solutions. The results are shown in Table 2. In general, $\mathrm{Si}$, $\mathrm{B}, \mathrm{Al}$, and $\mathrm{Ca}$ were detected in all solutions containing ISG samples, which is expected ${ }^{38}$. No Fe $(<0.1 \mathrm{ppm})$ was found in solutions containing SS samples, even for $\mathrm{SS}\left(+\mathrm{PTFE}_{\mathrm{NaCl}}\right)$, where severe localized corrosion occurred on SS and brown corrosion products were visible on the walls of the reactors. The absence of Fe in the solution could be attributed to the low solubility of $\mathrm{Fe}^{2+}$ or $\mathrm{Fe}^{3+}$ ions in alkaline solutions, as the solution $\mathrm{pH}$ value was about 8.4-8.6 after the corrosion testing (measured at room temperature). Under open circuit conditions, Fe tends to form insoluble iron oxides or hydroxides in this $\mathrm{pH}$ range ${ }^{44}$. Knowing the elemental concentrations in solution and assuming uniform alteration, the equivalent thickness (Eth) of altered glass was calculated. $B$ is one of the most soluble species in ISG, so the dissolution rate of $B$ is commonly used to express the corrosion rate of glass ${ }^{37}$. Correspondingly, the equivalent thickness of $B$, Eth (B), can be correlated to the gel layer thickness. Meanwhile, the fraction of each element being retained in the gel can be defined as retention factor (RF), which is given by $1-\operatorname{Eth}(i) / E \operatorname{th}(B)^{45}$. Since one side of ISG samples was shielded by other materials, the total effective surface area was not well defined. Therefore, the S/V value in Eq. 1 is not well defined. The calculation of Eth(i) was initially performed by including the contact surface area. The resulting $E$ th $(B)$ values were significantly lower than the actual thickness measured by SEM (Fig. 3f-i). In contrast, when the contact surface area was excluded, the Eth(B) values agreed reasonably well with the SEM results, especially for samples corroded in DI water. It is worth noting that the actual thickness of the gel on ISG(+PTFE $\left.\mathrm{NaCl}_{\mathrm{Na}}\right)$ falls between the $\mathrm{Eth}(\mathrm{B})$ values calculated using the two methods. However, the actual thickness of gels measured in the crevice mouth area of $\mathrm{ISG}\left(+\mathrm{SS}_{\mathrm{NaCl}}\right)$ was significantly higher than the higher estimated Eth(i) value, suggesting that the corrosion on this sample was strongly localized. In addition, the Eth(B) values for ISG corroded in $\mathrm{NaCl}$ solution are approximately twice those corroded in DI water, further validating that $\mathrm{NaCl}$ enhances the alteration of ISG, which agrees well with the XPS results. This may be attributed to the ion exchange between $\mathrm{Na}^{+}$in the solution and the $\mathrm{Ca}^{2+}$ ions in the ISG, which explains the strong depletion of Ca from the gel (low RF value). $\mathrm{Cl}^{-}$anions may also play a role in glass corrosion, but again, this effect is still not certain. Previous studies showed that the effect of cations in the leaching solution on initial dissolution rate dominate over anions ${ }^{46}$. Similar to $\mathrm{Ca}$, Al was almost depleted from the gel for ISG corroded in $\mathrm{NaCl}$, which is more evident for ISG $\left(+\mathrm{SS}_{\mathrm{NaCl}}\right)$. However, for ISG corroded in DI water, over $50 \%$ of $\mathrm{Ca}$ and $\mathrm{Al}$ was retained in the gel. The presence of $\mathrm{Ca}$ and $\mathrm{Al}$ has been known to limit the reactive diffusion coefficient of water within the gel layer ${ }^{37}$. Therefore, the deficit of these two elements in the gels formed in $\mathrm{NaCl}$ again suggests that the $\mathrm{NaCl}$ has an adverse impact on the durability of ISG.

\section{SEM energy dispersive X-ray spectroscopy analysis}

It should be noted that the analysis depth of XPS is $\sim 10 \mathrm{~nm}$, which is much smaller than the actual thickness of the gel. Therefore, EDS point analysis was performed on ISG $\left(+\mathrm{SS}_{\mathrm{NaCl}}\right)$, which is of the most interest, to further validate the change of gel chemistry due to the corrosion of SS. An acceleration voltage of $5 \mathrm{kV}$ was used, which results in an estimated analysis depth of $500 \mathrm{~nm}$ based on Kanaya-Okayama Range equation (Eq. 2) ${ }^{47}$. The gel formed on the contact side of the ISG $\left(+\mathrm{SS}_{\mathrm{NaCl}}\right)$ is heterogeneous, so EDS point analysis was conducted on the contact surface, rather than the cross-section of the gel. The examined area is shown in Fig. 5a, which is near the crevice mouth area. EDS data were collected from three locations and the concentrations of different elements were normalized to both $\mathrm{Al}$ (Fig. 5b) and Si (Fig. 5c). Due to the likely acidic environment existing in this region, normalization to 
Table 2. Analysis of the leaching solutions.

\begin{tabular}{|c|c|c|c|c|}
\hline Sample & $\operatorname{ISG}\left(+\mathrm{PTFE}_{\mathrm{NaCl}}\right)$ & $\begin{array}{l}\text { ISG } \\
\left(+\mathrm{SS}_{\mathrm{NaCl}}\right)\end{array}$ & ISG(+PTFE $\left.E_{D I W}\right)$ & $\begin{array}{l}\text { ISG } \\
\left(+S_{\text {DIW }}\right)\end{array}$ \\
\hline \multicolumn{5}{|c|}{ Elemental concentration/ppm } \\
\hline $\mathrm{Si}$ & 9.0 & 10.4 & 10.4 & 10.0 \\
\hline B & 6.3 & 6.4 & 3.4 & 3.1 \\
\hline $\mathrm{Al}$ & 3.6 & 3.8 & 0.9 & 0.7 \\
\hline $\mathrm{Ca}$ & 3.7 & 3.7 & 0.7 & 0.8 \\
\hline \multicolumn{5}{|l|}{ Solution $\mathrm{pH}$} \\
\hline $\mathrm{pH}_{\text {initial }}$ & 6.1 & 6.1 & $6.0^{\mathrm{a}}$ & $6.0^{\mathrm{a}}$ \\
\hline $\mathrm{pH}_{30 \text { days }}$ & 8.4 & 8.4 & 8.5 & 8.6 \\
\hline \multicolumn{5}{|c|}{ Equivalent thickness (including contact area in $S / V$ calculation $/ \mu m$ ) } \\
\hline $\operatorname{Eth}(\mathrm{Si})$ & 3.4 & 3.9 & 3.9 & 3.8 \\
\hline Eth(B) & 11.5 & 11.7 & 6.2 & 5.7 \\
\hline Eth(Al) & 11.1 & 11.7 & 2.8 & 2.2 \\
\hline $\operatorname{Eth}(\mathrm{Ca})$ & 10.2 & 10.2 & 1.9 & 2.2 \\
\hline \multicolumn{5}{|c|}{ Equivalent thickness (excluding contact area in $S / V$ calculation/ $\mu m$ ) } \\
\hline $\operatorname{Eth}(\mathrm{Si})$ & 5.2 & 6.1 & 6.1 & 5.8 \\
\hline Eth(B) & 17.9 & 18.2 & 9.6 & 8.8 \\
\hline $\operatorname{Eth}(\mathrm{Al})$ & 17.2 & 18.2 & 4.3 & 3.4 \\
\hline Eth(Ca) & 15.8 & 15.8 & 3.0 & 3.4 \\
\hline \multicolumn{5}{|c|}{ Retention factor } \\
\hline $\begin{array}{l}\text { Eth(Al)/Eth } \\
\text { (B) }\end{array}$ & 0.04 & 0 & 0.56 & 0.62 \\
\hline $\begin{array}{l}\text { Eth(Ca)/Eth } \\
\text { (B) }\end{array}$ & 0.12 & 0.14 & 0.70 & 0.62 \\
\hline $\begin{array}{l}\text { Eth(Si)/Eth } \\
\text { (B) }\end{array}$ & 0.71 & 0.67 & 0.37 & 0.34 \\
\hline
\end{tabular}

${ }^{\mathrm{a}}$ Due to the large ohmic potential drop in DI water, a small amount of KC salt $(0.03 \mathrm{M})$ was added to $\mathrm{DI}$ water for the accurate measurement of solution $\mathrm{pH}^{75}$.

Si may be more reliable because other elements are soluble in such conditions. Similar trends were observed for the two normalization methods, where $\mathrm{Na}, \mathrm{Al}$, and $\mathrm{Zr}$ were depleted in an area that is about $2 \mathrm{~mm}$ within the boundary of the crevice. This led to the formation of a more silica-like gel, which is consistent with XPS results. The localized corrosion on ISG at a particular distance from the boundary of the crevice may be associated with the competition between SS dissolution, which is affected by the ohmic potential drop, and the diffusion of metal cations out of the crevice.

It is also worth noting that for ISG $\left(+\mathrm{SS}_{\mathrm{NaCl}}\right)$, the solution analysis results suggest a complete depletion of $\mathrm{Al}$, but the XPS results indicate that Al was slightly enriched on the non-contact side compared to the pristine ISG. SEM imaging on the cross-section of this sample showed that the non-contact side exhibits a uniform gel layer. Therefore, EDS analysis was conducted on the crosssection to further assess the chemical composition of the gel formed on the non-contact side. As shown in Fig. $5 d$, the gel seems to have a bi-layer structure, consisting of a thin outer layer and a thick inner layer. EDS point analyses were collected on five different spots with results summarized in Fig. 5e and Table 3. The compositions were normalized to $\mathrm{Zr}$, which is the least soluble cation in the bulk solution (neutral to alkaline). Ca was depleted from the gel almost completely, which is consistent with the solution analysis and XPS data. The dissolution of Si and Al seems to be depth-dependent, as they were almost completely depleted from the outermost layer with a concentration gradient across the gel. Combining the results obtained via the three techniques, it can be concluded that Al depletion may occur under the testing conditions, and that it is depth dependent. While most Al was depleted within several microns of the surface as revealed by the EDS and solution analysis, it partially reprecipitated back on the gel surface, which explains the enrichment of Al on the outermost layer as observed by XPS. This Al rich layer was much thinner than the gel, with a different chemistry, so it did not seem to result from gel self-reorganization. Instead, the layer is more likely a consequence of precipitation at the interface of solution and the gel. Given the fact that the solution was not saturated in silica, the occurrence of dissolution and reprecipitation is likely. Interestingly, $\mathrm{Cl}^{-}$was detected in the gel layer, which could be attributed to the porosity of the gel ${ }^{48}$.

Silicate network changes on corroded ISG surface

SR-IR spectroscopy was used to probe the changes of silicate networks on the corroded ISG surface (Fig. 6). All spectra were collected at the center of the crevice area, as well as the noncontact area to further explore the effect of leaching solutions. For ISG samples altered in $\mathrm{NaCl}$ solutions (Fig. 6a, b), B was completely leached out from the surface layer (to a depth of $\sim 10 \mu \mathrm{m}$ ) as no $\mathrm{B}-\mathrm{O}$ band was observed at $1380 \mathrm{~cm}^{-149}$, which is consistent with the solution analysis and XPS results. However, for ISG that were immersed in DI water (Fig. 6c, d), B-O band still exists although the peak intensity was lower than the pristine ISG. Since the analysis depth for SR-IR is about $10 \mu \mathrm{m}$ in the B-O stretch region ${ }^{50}$ and the gel layers for ISG altered in DI water are slightly thinner than this value, B may originate from the underlying pristine ISG. For pristine ISG, the asymmetric stretch vibrational mode of $\mathrm{Si}-\mathrm{O}-\mathrm{Si}$ shows up at $1038 \mathrm{~cm}^{-1}$. For all corroded ISG samples, this peak shifted to a higher wavelength of $1066 \mathrm{~cm}^{-1}$ due to ion exchange and Si network reorganization. The blue shift of the $\mathrm{v}_{\mathrm{Si}-\mathrm{O}-\mathrm{Si}}$, as peak also implies a shorter length of the $\mathrm{Si}-\mathrm{O}$ bond in the alteration layer, indicating the build-up of tensile stress on the altered glass surface. As the alteration layer gets thicker, such stress may eventually exceed the cohesive strength of the alteration layer causing mechanical instability. For all corroded ISG samples, two new peaks appear near 788 and $896 \mathrm{~cm}^{-1}$, which have been attributed in a previous study ${ }^{51}$ to the stretching vibrations of $\mathrm{SiO}_{4}$ (corner-sharing tetrahedra) with $\mathrm{A} 1\left(\mathrm{U}_{\left.\mathrm{SiO}_{4}, \mathrm{~A}_{1}\right)}\right)$ and $\mathrm{T} 2\left(\mathrm{U}_{\mathrm{SiO} 4}, \mathrm{~T}_{2}\right)$ symmetry, respectively. These two peaks are more evident for ISG corroded in $\mathrm{NaCl}$ solution, suggesting a higher degree of network changes. However, no visible changes were identified between ISG $\left(+\mathrm{SS}_{\mathrm{NaCl}}\right)$ and ISG $\left(+\right.$ PTFE $\left._{\mathrm{NaCl}}\right)$, or between ISG $\left(+\mathrm{SS}_{\mathrm{DIW}}\right)$ and ISG $\left(+P_{T F E} E_{D I W}\right)$. Also, no significant differences were observed between different locations. These results indicate, that within the depth that SR-IR can measure, $\mathrm{Na}^{+}$ion exchange may be the dominant reaction for ISG corrosion under these testing conditions due to its high chemical durability. Therefore, studies with longer durations are required (currently ongoing) to identify any differences.

\section{Corrosion of stainless steel}

It was reported previously that, when SS and ISG were exposed together in $\mathrm{NaCl}$ solution, the corrosion of SS was suppressed by ISG ${ }^{16}$ (also see Fig. 7a, b). The reduced corrosion rate on SS may be associated with a continuous film formed on $\mathrm{SS}\left(+\mathrm{ISG}_{\mathrm{NaCl}}\right)$ surface, consisting of almost all major elements in SS and ISG. This layer may act as a physical barrier and protect the SS matrix from the corrosive medium. In this study, when DI water was used as the leaching solution, no crevice corrosion was identified on SS $\left(+\mathrm{ISG}_{\mathrm{DIW}}\right)$ or $\mathrm{SS}\left(+\mathrm{PTFE}_{\mathrm{DIw}}\right)$. However, pitting corrosion is still visible on multiple locations of $\mathrm{SS}\left(+\mathrm{ISG}_{\mathrm{DIw}}\right)$ (Fig. 7c), but less evident on $\mathrm{SS}\left(+\mathrm{PTFE}_{\mathrm{DIW}}\right)$ (Fig. 7d, e), suggesting that elements leached from ISG may accelerate the pitting corrosion of SS under the testing conditions. It is unlikely that $\mathrm{B}, \mathrm{Na}$, or $\mathrm{Si}$ are the cause of the attack. However, previous studies by Kim et al. showed that 


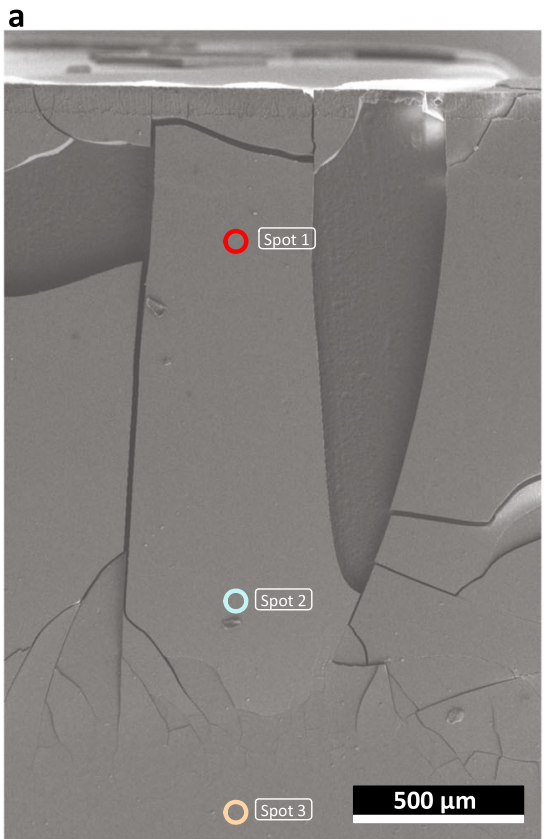

b

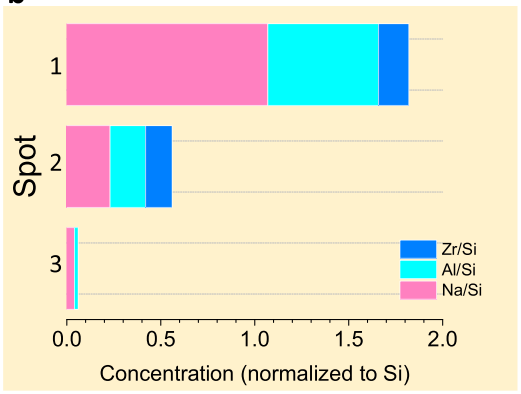

C

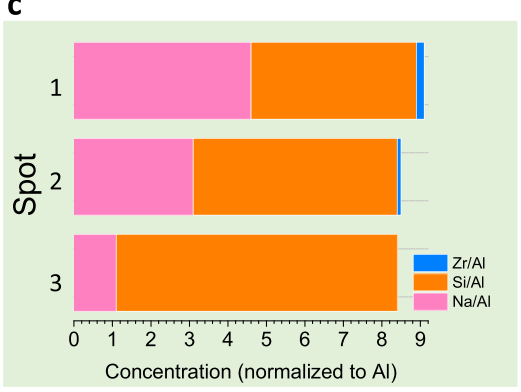

d

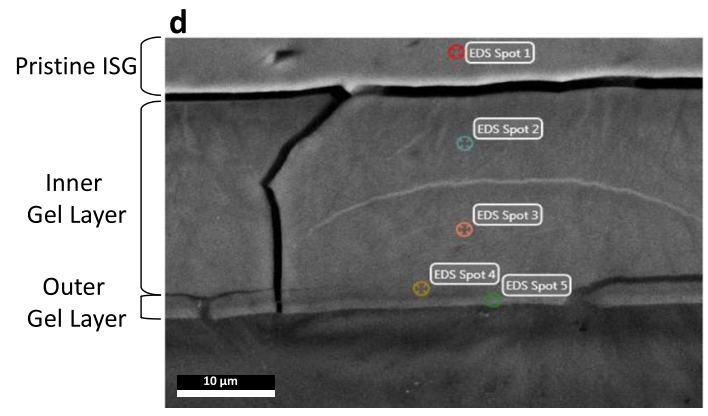

e

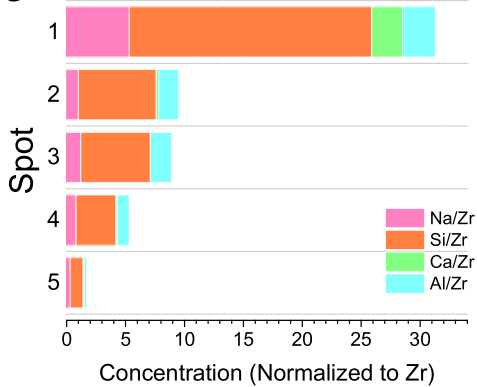

Fig. 5 SEM images and EDS point analysis for the ISG( $\left.+\mathbf{S S}_{\mathrm{NaCl}}\right)$. a Surface morphology near the crevice mouth area (contact side). EDS point analysis was collected on three different locations and the results were normalized to $\mathbf{b}$ Si and $\mathbf{c}$ Al. $\mathbf{d}$ Cross-section of gel layer formed on the non-contact side. e EDS point analysis for five selected spots of the gel layer.

Table 3. Chemical composition of gels formed on the non-contact side of ISG $\left(+\mathrm{SS}_{\mathrm{NaCl}}\right)$.

\begin{tabular}{lcrrrrr}
\hline Element & Nominal & Spot 1 & Spot 2 & Spot 3 & Spot 4 & Spot 5 \\
\hline $\mathrm{O}$ & 50.1 & 51.9 & 36.9 & 36.2 & 40.4 & 42.9 \\
$\mathrm{Na}$ & 9.0 & 8.0 & 5.7 & 7.7 & 7.5 & 6.5 \\
$\mathrm{Al}$ & 3.2 & 4.2 & 10.2 & 10.8 & 9.2 & 4.7 \\
$\mathrm{Si}$ & 26.3 & 30.7 & 38.6 & 36.3 & 30.6 & 22.0 \\
$\mathrm{Zr}$ & 2.4 & 1.5 & 5.9 & 6.2 & 9.0 & 19.8 \\
$\mathrm{Ca}$ & 3.6 & 3.8 & 1.3 & 0.0 & 0.6 & 1.1 \\
$\mathrm{Cl}$ & 0.0 & 0.0 & 0.8 & 1.8 & 2.1 & 2.4 \\
$\mathrm{Normalized}$ & Composition & & & & & \\
$\mathrm{Na} / \mathrm{Zr}$ & 3.8 & 5.3 & 1.0 & 1.2 & 0.8 & 0.3 \\
$\mathrm{Si} / \mathrm{Zr}$ & 11.0 & 20.6 & 6.6 & 5.9 & 3.4 & 1.1 \\
$\mathrm{Ca} / \mathrm{Zr}$ & 1.5 & 2.6 & 0.2 & 0.0 & 0.1 & 0.1 \\
$\mathrm{Al} / \mathrm{Zr}$ & 1.3 & 2.8 & 1.7 & 1.8 & 1.0 & 0.2 \\
Loss of Si (\%) based on Zr & 68.1 & 71.3 & 83.6 & 94.6 \\
Loss of Ca (\%) based on Zr & 91.2 & 100.0 & 97.5 & 97.8 \\
Loss of Al (\%) based on Zr & 39.3 & 35.7 & 64.3 & 92.9 \\
\hline
\end{tabular}

$\mathrm{Al}^{3+}$ can accelerate the corrosion rate of SS at elevated temperature $\left(80^{\circ} \mathrm{C}\right)$ by lowering the pitting potential while increasing the passive current density ${ }^{52}$. Liu et al. also showed clear evidence that even a low amount of $\mathrm{Al}^{3+}$ enhanced the mass transport limited cathodic kinetics of SS at room temperature ${ }^{53}$. A mechanism based on Grotthuss theory ${ }^{54}$ was proposed by the authors, where the presence of $\mathrm{Al}^{3+}$ ions lowered the bond strength of $\mathrm{O}-\mathrm{H}$ in water molecules. This process facilitated the transport of protons from the solution to the metal surface, leading to the increased cathodic kinetics. Therefore, when DI water is used as the leaching solution, SS corrosion may be accelerated by ISG corrosion. However, the occurrence of pitting corrosion is still unexpected, since no aggressive anions (e.g., $\mathrm{Cl}^{-}$) are present in the solution. None of the dissolved species from ISG corrosion is likely to break down the passive film of the SS. To further study this phenomenon, a separate electrochemical experiment was performed. A SS specimen was potentiodynamically polarized in the 30-day-leaching solution of ISG(+PTFE $\left.E_{\text {DIw }}\right)$ with composition shown in Table 2. The polarization curve is given in Fig. 8a. A low corrosion current density on the order of $10^{-7} \mathrm{~A}$ / $\mathrm{cm}^{2}$ was observed, indicating spontaneous passivity of the $\mathrm{SS}$. The SS remained generally passive in the potential range of 100-500 $\mathrm{mV}_{\mathrm{SCE}}$, but a small current peak is evident near $150 \mathrm{mV}_{\mathrm{SCE}}$. This 
a

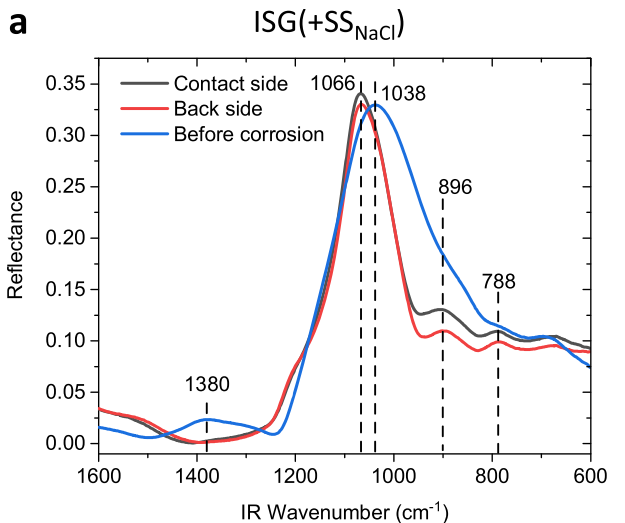

C

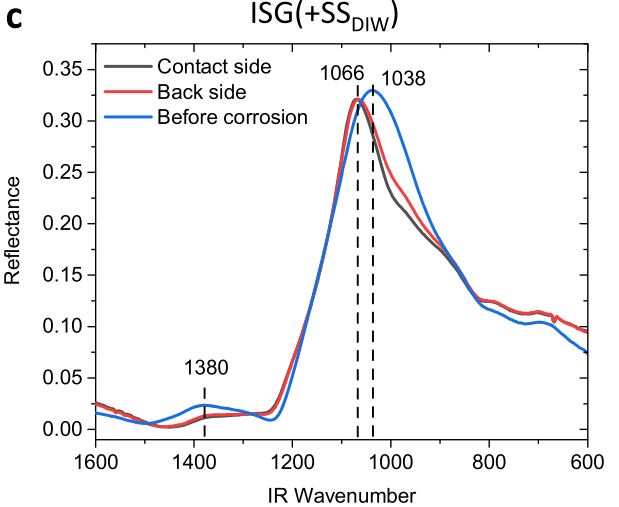

b

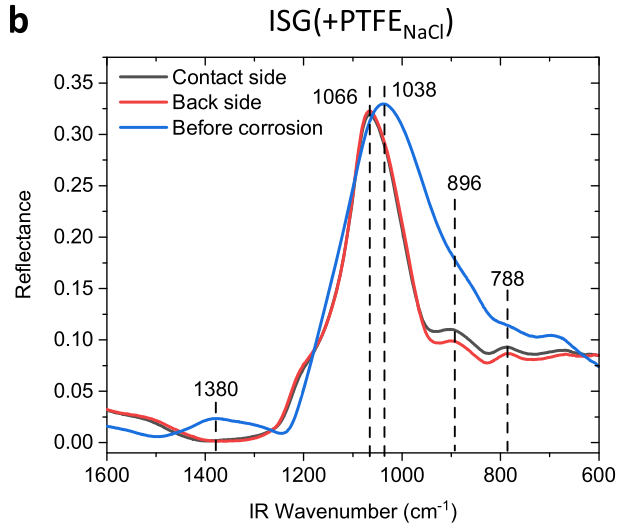

d

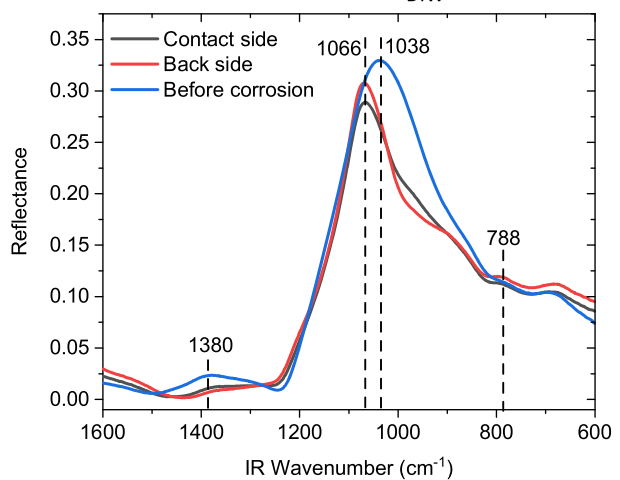

Fig. 6 SR-IR spectra for the corroded ISG samples. a ISG $\left(+\mathrm{SS}_{\mathrm{NaCl}}\right)$, b ISG $\left(+\mathrm{PTFE}_{\mathrm{NaCl}}\right)$, $\mathbf{c I S G}\left(+\mathrm{SS}_{\mathrm{DIW}}\right)$, d ISG(+PTFE $\left.\mathrm{DIW}_{\mathrm{DIw}}\right)$. For each sample, the spectra were collected from two different locations, including the area in direct contact with SS or PTFE (contact side) and the area in contact with PFA container (Back side). Spectrum acquired from pristine ISG was also plotted for as a reference.

peak is probably not associated with the oxidation of species in the ISG leaching solution, which are likely in their maximum oxidation state. Other authors have reported a similar current when the SS was potentiodynamically polarized in solutions containing $\mathrm{F}^{-}$ions ${ }^{55}$. Cao et al. observed a similar peak at 380 $\mathrm{mV}_{\mathrm{SCE}}$, which only occurred in solutions with high $\mathrm{F}^{-}$ions $(0.1 \mathrm{M})$. However, the concentration of $F$ in this study was below $0.1 \mathrm{ppm}$, suggesting a more complicated mechanism probably involving the complexation of dissolved species from ISG. Small current transients likely associated with metastable pitting events were identified from 300 to $500 \mathrm{mV}_{\mathrm{SCE}}$, indicative of passive film instability. A breakdown potential appeared at $500 \mathrm{mV}_{\text {SCE }}$ suggesting that localized corrosion occurred. When the current density approached $1 \mathrm{~mA} / \mathrm{cm}^{2}$, the increase of current density slowed down, which was associated with ohmic potential drop in the cell. Upon reversal of the scan direction, the current density remained large. This positive hysteresis loop is a diagnostic indication that the breakdown was indeed caused by localized corrosion. After polarization, the SS surface was examined in an SEM. Although pitting corrosion was not observed, extensive crevice corrosion was evident (Fig. 8b), which supports the evidence of localized corrosion provided by the potentiodynamic polarization curve. The presented crevice corrosion occurred in the contact area of the SS and the O-ring, which was a component of the electrochemical cell designed for preventing solution leakage. The occurrence of crevice corrosion is also consistent with the unexpected pitting corrosion identified on the SS $\left(+\mathrm{ISG}_{\mathrm{DIW}}\right)$. These localized corrosion events might be explained by the presence of $\mathrm{F}^{-}$ions in the ISG(+PTFE $\mathrm{DIW}_{\mathrm{W}}$ ) leaching solution, which could have originated from the PFA containers and PTFE specimens. Note that the PFA containers and PTFE specimens were all pretreated to remove $\mathrm{F}^{-}$ions according to ASTM $\mathrm{C} 1285^{56}$.
However, the $\mathrm{F}^{-}$ions were probably not completely eliminated because $F$ is one of the primary components of both PFA and PTFE. The observation suggests that localized corrosion could occur at the interface of metal canisters and nuclear waste glass, even with a low amount of aggressive anions that is below the detection limit of ICP-OES. Therefore, the corrosion interaction observed at the metal and glass interface seems to be difficult to avoid, so it should be carefully considered in future models for materials corrosion. Besides crevice corrosion, Si-bearing phases were found to be precipitated on the SS surface (Fig. 8c). Upon closer examination, the particles also contained $\mathrm{Ni}, \mathrm{Fe}$, and $\mathrm{Cr}$ (Table 4), which originated from SS corrosion. EDS elemental maps were also collected on the lacy covers surrounding the crevice damage, because these passive film remnants are thin enough and enable the characterization of outermost surface layer without interference from the SS matrix. As shown in Fig. 9, the surface film primary consists of $\mathrm{Fe}, \mathrm{Ni}, \mathrm{Mo}$, and $\mathrm{Cr}$, which are the major elements from SS. However, a layer of $\mathrm{Si}$ is visible across the entire surface, which originated from the ISG leaching solution. The co-precipitation of $\mathrm{Si}$ and metal cations in the secondary phases, along with the observation of continuous Si-rich film on SS surface indicates that the corrosion of SS could delay the saturation of silicates near the glass and thus enhance the glass corrosion, which is consistent with the previous results obtained at the open circuit potential ${ }^{16}$.

\section{DISCUSSION}

An oxic environment was used in this study, which is relevant to the U.S. Yucca Mountain project ${ }^{57}$. Although anoxic disposal conditions have been considered by many countries, an anoxic condition is not likely to be maintained throughout the lifetime of 
a

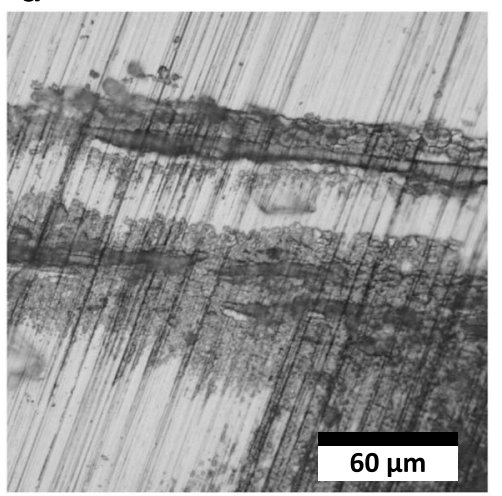

C

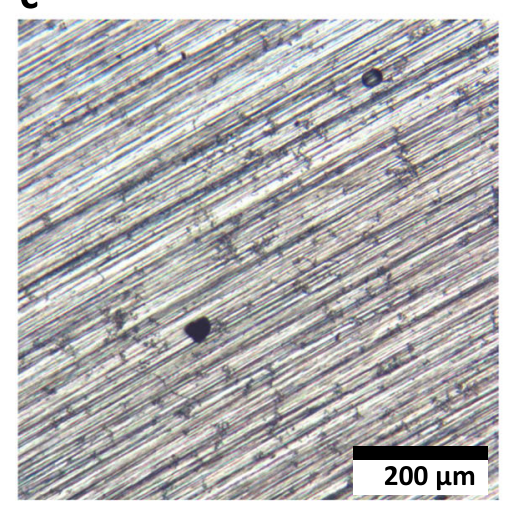

b

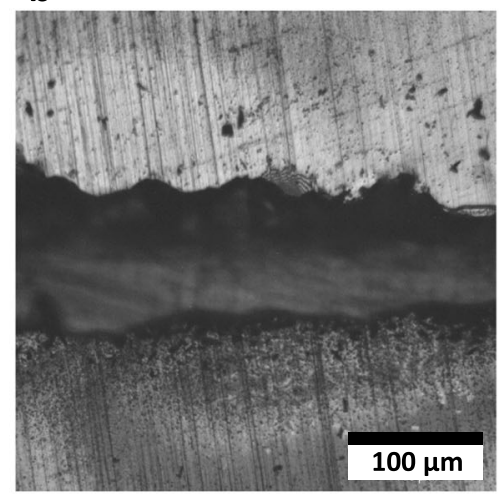

d

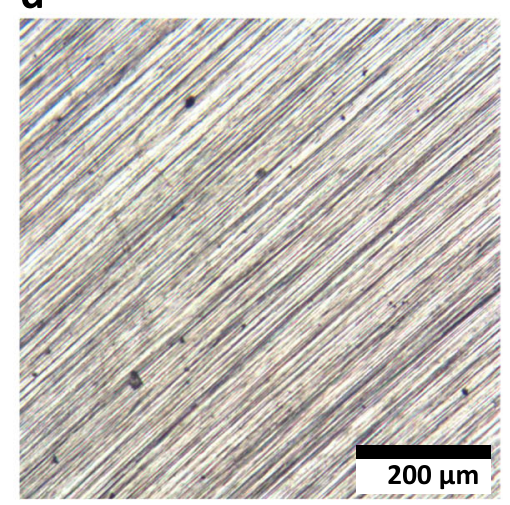

e<smiles>CC(C)(C)c1ccccc1</smiles>

E

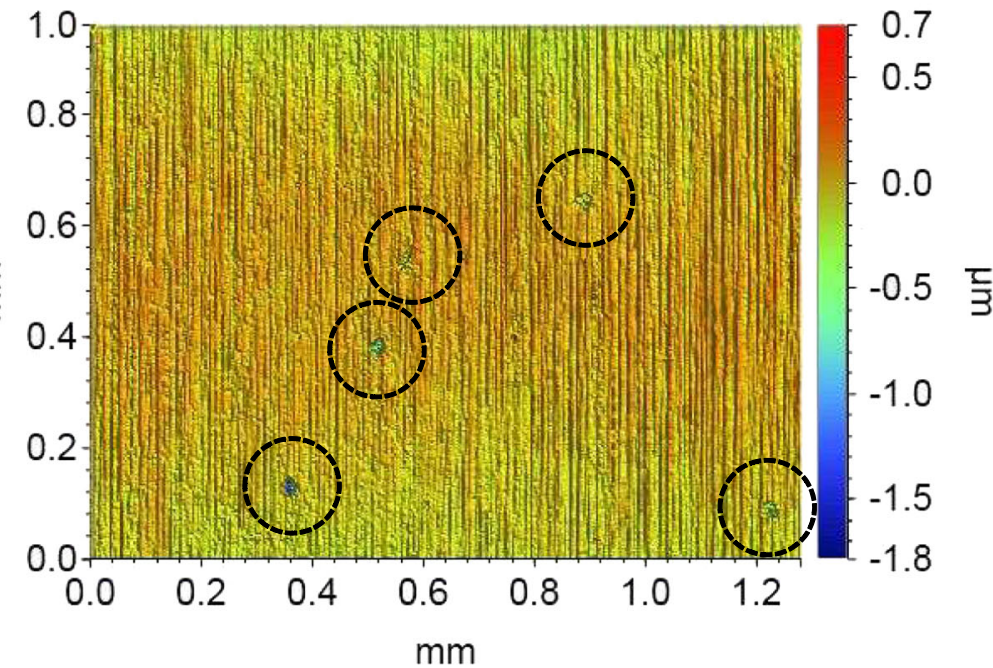

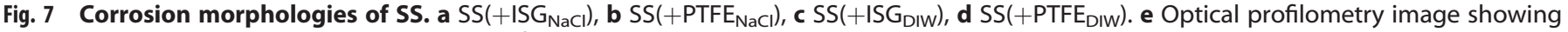
pitting corrosion observed on a typical area of SS(+PTFE $\left.E_{\text {IIW }}\right)$. Visible pits are indicated in black circles.

disposal ${ }^{58}$. Oxygen will be introduced during the excavation and waste emplacement ${ }^{59}$, which is likely to exist for a certain period of time until consumed by corrosion or other processes. The dissolved oxygen has been considered in Canadian waste assessment models, while other oxidants could be present in different environments proposed by other countries ${ }^{58}$. Additionally, the water radiolysis introduced by the incorporated radionuclides within the waste package may generate various oxidants $^{60}$. Due to the mass transport limitation, these oxidants are likely to be depleted within the confined interfacial space between the metallic canisters and encapsulated waste forms, a process similar to oxygen depletion during crevice corrosion. Therefore, although this study was conducted in an oxic environment, the disclosed corrosion mechanism could still be applied to anoxic environments.

Whether water could be present in the repository is also an important and valuable argument. At the potential Yucca Mountain site in U.S., perched water exists in the rock pores ${ }^{61,62}$. During the heat up phase of the long thermal cycle that Yucca Mountain will experience, this water will be driven away from the hot drifts. However, in the cooling phase, the water will come back down into the drift. It should be noted that the presence of an aqueous environment is not limited to the U.S. Yucca Mountain repository. For all of the repositories being considered by every nation with nuclear waste, whether in granite, clay or tuff, the most likely scenario involves a first stage of desaturation tied to 
a

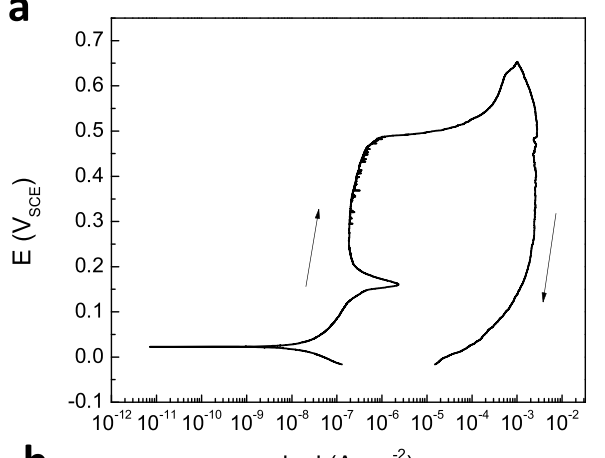

b $\operatorname{logi}\left(\mathrm{A} \cdot \mathrm{cm}^{-2}\right)$

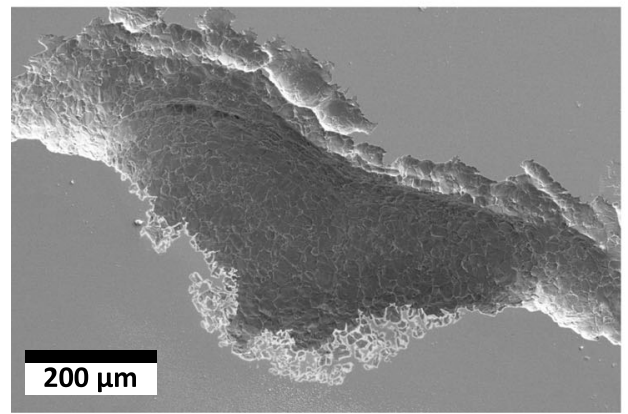

C
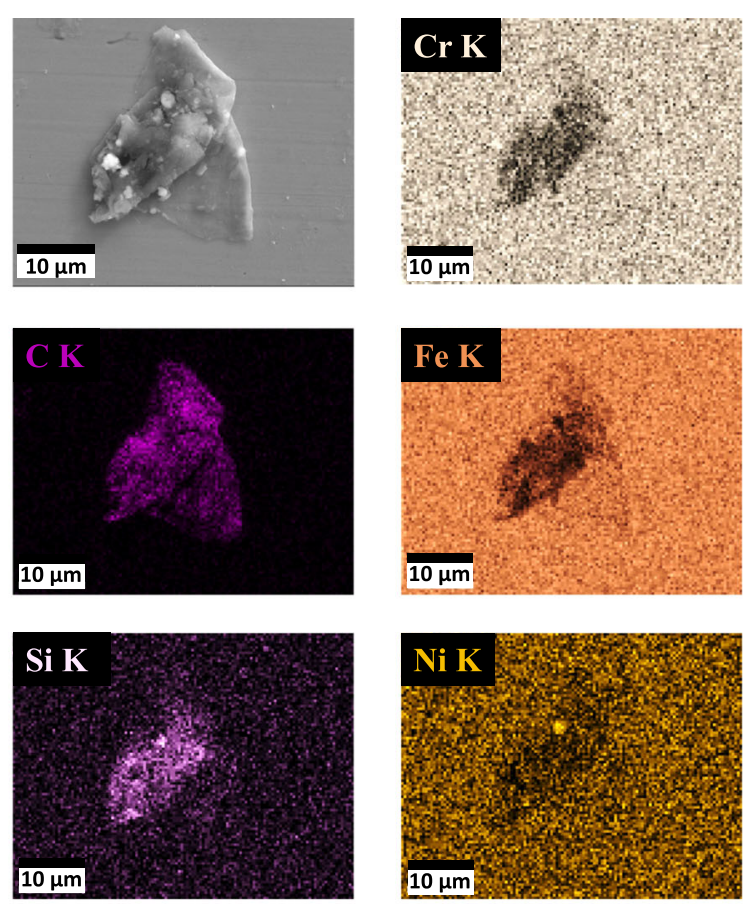

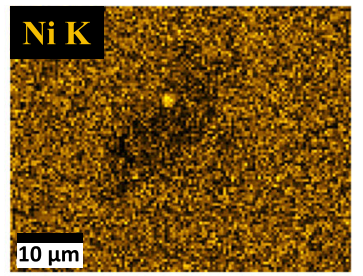

Fig. 8 Effect of ISG on SS corrosion. a potentiodynamic polarization of SS in the 30-day-leaching solution of ISG(+PTFE $E_{D I w}$ ). $\mathbf{b}$ Crevice corrosion damage observed after the polarization. c SEM and EDS elemental mapping of secondary phase precipitated on the SS after polarization. The EDS elemental quantification results are listed in Table 4.

\begin{tabular}{|c|c|c|c|c|c|c|c|}
\hline Element & Atomic \% & Intensity (counts) & Error \% & Element & Atomic \% & Intensity (counts) & Error \% \\
\hline C K & 31.9 & 318.4 & 9.5 & Si K & 2.2 & 96.8 & 7.9 \\
\hline Si K & 0.7 & 107.6 & 9.1 & Mo L & 1.5 & 82.3 & 10.2 \\
\hline $\mathrm{Cr} \mathrm{K}$ & 13.3 & 2343.2 & 2.1 & $\mathrm{Cr} \mathrm{K}$ & 23.9 & 278.5 & 6.7 \\
\hline $\mathrm{Ni} \mathrm{K}$ & 6.3 & 661.3 & 3.2 & $\mathrm{Ni} \mathrm{L}$ & 5.6 & 141.1 & 12.6 \\
\hline
\end{tabular}
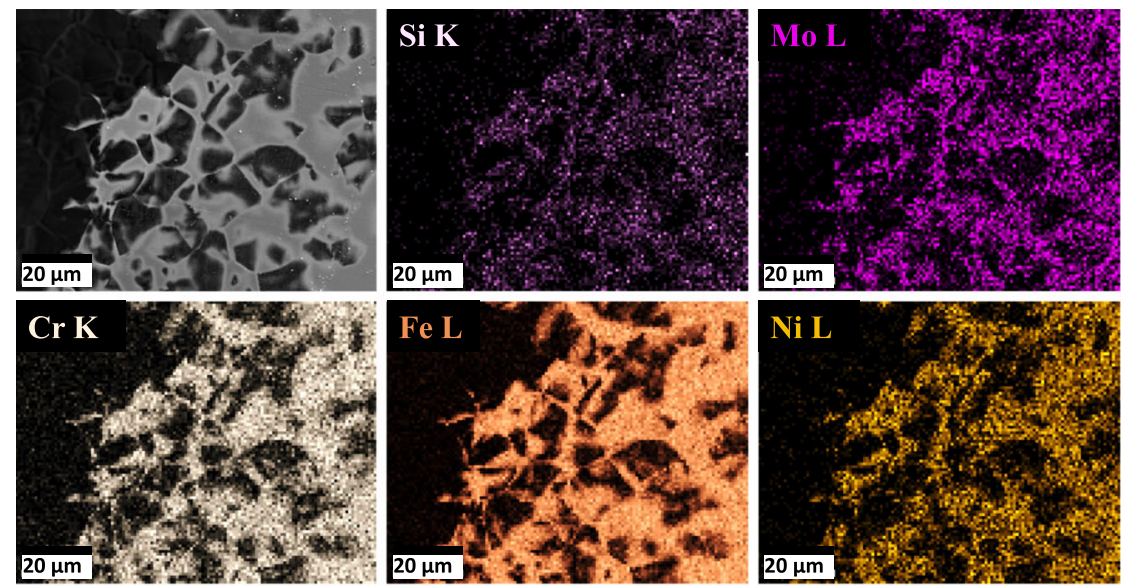

Fig. 9 EDS elemental mapping of the SS surface after potentiodynamic polarization. The EDS elemental quantification results are listed in Table 4. 
the heat production from the wastes, followed by a second stage of resaturation by ground water ${ }^{63}$. Therefore, water is highly likely to be present in the repository ${ }^{16,62,64}$. The safety demonstration requirements are that all corrosion processes in vapor or liquid water that potentially affect the waste form performance must be studied in detail. It is thus a reasonable assumption that water could exist and induce corrosion in the repository.

Preliminary study of metal and glass corrosion interaction was performed with several corrosion resistant alloys and a commercial SLSG, which was used as a model boron-free glass. Although only a few techniques were used to characterize the corroded samples, the corrosion mechanism has been revealed, owing to the high corrosion rate of SLSG. The study was then extended to the more complicated system of ISG, a reference six-oxide borosilicate glass, and SS to gain mechanistic understanding of the potential near-field corrosion interactions between nuclear waste glass and metallic canister materials.

The interactions of SS and glass led to similar corrosion morphologies on SLSG and ISG as shown in Figs. 1 and 3, respectively. However, there are some differences. Visual observation suggests that the band pattern is more evident on SLSG $\left(+\mathrm{SS}_{\mathrm{NaCl}}\right)$, although the exposure time was half that of ISG $\left(+\mathrm{SS}_{\mathrm{NaCl}}\right)$. Two bands were observed on $\mathrm{SLSG}\left(+\mathrm{SS}_{\mathrm{NaCl}}\right)$, while only one band was identified on ISG $\left(+\mathrm{SS}_{\mathrm{NaCl}}\right)$. This could be attributed to the different sizes of specimens used. For the SLSG and SS interaction study, the SS specimen was smaller than the SLSG. Therefore, when the two specimens were pressed against each other, crevice corrosion of SS occurred within the contact area, leading to the formation of the inner band. The shape of the outer band matches perfectly with the boundary of the contact area, so it is most likely affected by the cathodic ORR. In contrast, for the ISG and SS interaction study, the SS specimen was intentionally larger than the ISG. A larger SS specimen with a small contact area can result in a larger cathode-to-anode ratio, thereby increasing the rate of localized corrosion on $\mathrm{SS}^{65}$ and thus accelerate the corrosion of nearby ISG. Since the SS specimen was larger, the entire contact area of ISG was exposed to the crevice environment, which was primarily the anodic sites. Therefore, only one band was identified on the $\mathrm{ISG}\left(+\mathrm{SS}_{\mathrm{NaCl}}\right)$ associated with acidic attack.

Interestingly, Fe was only detected in the inner band on SLSG $\left(+\mathrm{SS}_{\mathrm{NaCl}}\right)$ while $\mathrm{Cr}$ was exclusively found in the outer band (Fig. 2). Both elements originated from SS corrosion and they seemed to be incorporated into the gel network as indicated by SR-IR, although in different locations. $\mathrm{Cr}(\mathrm{OH})_{3}$ has a low solubility in acidic conditions ${ }^{7}$, so the absence of $\mathrm{Cr}$ in the inner band suggests

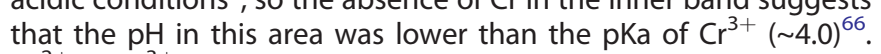
$\mathrm{Fe}^{2+}$ or $\mathrm{Fe}^{3+}$ is also soluble in such acidic environment, but in the inner band region, the solubility of these cations may be limited by their bonding with the glass network. This may also explain the existence of $\mathrm{Fe}$ on the surface of $\mathrm{ISG}\left(+\mathrm{SS}_{\mathrm{NaCl}}\right)$. Due to the high solubility of $\mathrm{Fe}$ and $\mathrm{Cr}$ in the crevice mouth region and the existence of a concentration gradient, part of metal cations diffused from the crevice to the bulk solution and precipitated as metal hydroxides when they met the neutral or alkaline bulk solution. In the bulk environment, the solubility of $\mathrm{Cr}(\mathrm{OH})_{3}$ is lower than $\mathrm{Fe}(\mathrm{OH})_{2}$ or $\mathrm{Fe}(\mathrm{OH})_{3}{ }^{7}$, so the formation of $\mathrm{Cr}(\mathrm{OH})_{3}$ is thermodynamically more favorable. This may explain the presence of $\mathrm{Cr}$ in the outer band. Compared to ISG $\left(+\mathrm{SS}_{\mathrm{NaCl}}\right)$, less $\mathrm{Fe}$ was identified on the surface of SLSG( $+\mathrm{SS}_{\mathrm{NaCl}}$ ) (Figs. 2 and 4), which may be associated with the shorter exposure time of SLSG and SS (Table 1).

We previously reported that SS corrosion in $\mathrm{NaCl}$ solution was reduced by the presence of ISG, which was attributed to the formation of Si-rich surface film on $\mathrm{SS}^{16}$. In this study, it is shown that the localized corrosion of SS seems to be accelerated when DI water is used as the leaching solution, likely due to the presence of $\mathrm{Al}^{3+}$ ions from ISG corrosion. These results suggest that the interaction of glass and SS corrosion is solution dependent. In solutions containing abundant aggressive anions, the pit growth kinetics of SS may dominate ${ }^{67}$. The precipitation of silicate film on SS surface may inhibit such reactions, by blocking the anodic dissolution and suppressing cathodic kinetics. Under these conditions, the effect of $\mathrm{Al}^{3+}$ could be ignored since the pit initiation is not rate limiting. However, under mild conditions (e.g. DI water) where a limited amount of aggressive anions are available, the stability of SS passive film may dominate. The presence of $\mathrm{Al}^{3+}$ ions may undermine the integrity of SS passive film ${ }^{52}$, resulting in a deleterious effect on SS corrosion.

Silicates have been known to be good corrosion inhibitors for various metals, including carbon steel ${ }^{68-71}$, magnesium alloys ${ }^{70}$, and aluminum alloys ${ }^{72}$. The inhibition mechanism has been well studied. It is generally believed that silicates form a protective film on the metal surface, which consists of metal oxides and silicon oxide, depending on the environment and the properties of metal substrates. However, McVay et al..$^{9}$ reported that the corrosion of steel was enhanced by the presence of glass. The authors suggested that the formation of insoluble Fe-silicate colloids may continuously drive the dissolution of steel. This contradiction may also be explained by the differences in the aggressiveness of the environment. In the studied conducted by McVay et al., synthetic groundwater of slightly alkaline initial $\mathrm{pH}(7.5-10.0)$ and low aggressiveness was used. The corrosion of glass was also likely to increase the $\mathrm{pH}$ of the bulk solution, which promoted the formation of oxides on the steel. Under these conditions, the breakdown of the passive film may be rate limiting. Due to the low concentration of $\mathrm{Cl}^{-}$ions in groundwater, the primary corrosion mechanism of steel may be via passive dissolution or metastable pitting, which generates limited amount of $\mathrm{Fe}^{2+}$ ions. These $\mathrm{Fe}^{2+}$ ions combined with silicates species in the solution and form insoluble Fe-silicates colloids. In comparison, for most studies involving silicates as corrosion inhibitors, the solution environment is generally more aggressive $(>0.5 \mathrm{M} \mathrm{NaCl})$, so oxide stability may not be rate limiting in those cases.

The Fe-silicate precipitation mechanism may have also occurred in this study for ISG specimens leached in DI water. Only the SS $\left(+\mathrm{PTFE}_{\mathrm{DIW}}\right)$ leach solution contained Fe at sufficient concentration to be detectable by ICP-OES ( 0.6 ppm). The final $\mathrm{pH}$ for this solution was 4.6 , which explains the stability of $\mathrm{Fe}^{2+}$ or $\mathrm{Fe}^{3+}$ ions. In contrast, no Fe was detected in the $\mathrm{SS}\left(+\mathrm{ISG}_{\mathrm{DIW}}\right)$ leach solution with a final $\mathrm{pH}$ of 8.6. However, as shown in Fig. 7c, d, the pitting damage on $\mathrm{SS}\left(+\mathrm{ISG}_{\mathrm{DIw}}\right)$ is clearly more severe than that of SS $\left(+\mathrm{PTFE}_{\mathrm{DIW}}\right)$. This suggests that $\mathrm{Fe}^{2+}$ ions resulted from the corrosion of $\mathrm{SS}\left(+\mathrm{ISG}_{\mathrm{DIW}}\right)$ may have been removed from the leaching solution by the precipitation of insoluble Fe-silicates. This mechanism, along with the acceleration effect of $\mathrm{Al}^{3+}$ ions, may explain the enhanced corrosion rate of SS altered in close proximity to ISG in DI water.

Combining all observations, it may be concluded that corrosion interactions exist between the metallic canisters and glass waste form when they are exposed in aqueous environment. The localized corrosion of metals creates an aggressive environment by generating metal cations. These cations could be incorporated into the gel network, leading to the change of gel structure and chemistry, generating local stress that could undermine the mechanical integrity of the gel layer, and eventually result in the release of incorporated radionuclides. The hydrolysis of the metal cations also acidifies the local environment, which significantly affects the corrosion of nearby glass. These interactions could not be avoided even with extremely corrosion resistant alloys. Additionally, these interactions seem to be solution dependent. In a real repository environment, the interactions could be more complicated. For example, this study was conducted in an oxic environment, which is the expected condition for the repository under consideration by the U.S. Yucca Mountain project ${ }^{57}$. However, most other countries are considering anoxic repository 
Table 5. Chemical composition of materials in weight percent.

\begin{tabular}{|c|c|c|c|c|c|c|c|c|c|c|}
\hline & Si & B & $\mathrm{Na}$ & Al & $\mathrm{Ca}$ & $\mathbf{Z r}$ & 0 & & & \\
\hline$S L S G^{a}$ & 39.8 & 0 & 7.4 & 0 & 3.3 & 0 & 49.4 & & & \\
\hline \multirow[t]{2}{*}{ SS316 } & 0.018 & 1.257 & 0.037 & 0.001 & 0.270 & 16.669 & 10.070 & 2.010 & 0.052 & Balance \\
\hline & Co & $\mathrm{Mn}$ & $\mathbf{w}$ & $\mathrm{Cu}$ & $\mathbf{S i}$ & $\mathrm{Cr}$ & $\mathbf{N i}$ & Mo & $\mathrm{Nb}$ & $\mathrm{Fe}$ \\
\hline G30 & C & Mn & Al & $\mathbf{S}$ & Co & $\mathrm{Cr}$ & $\mathbf{N i}$ & Mo & $\mathbf{N b}+\mathbf{T a}$ & $\mathrm{Fe}$ \\
\hline A625 & $<0.1$ & $<0.5$ & $<0.4$ & $<0.015$ & 1.0 & $20.0-23.0$ & 58.0 & $8.0-10.0$ & $3.15-4.15$ & 5.0 \\
\hline
\end{tabular}

environments. In such conditions, the hydrogen evolution reaction would be the more likely dominant cathodic reaction on metallic canisters rather than ORR. It would be of interest to study the interactions of metallic canisters and nuclear waste glass in this condition. Additionally, the underground water chemistry is much more complicated than the $\mathrm{NaCl}$ solution or $\mathrm{DI}$ water used in this study. We have shown here that $\mathrm{Al}^{3+}$ originating from ISG corrosion may have an adverse effect on SS corrosion. However, the real nuclear waste glass may include more than half elements from the periodic table, so a wide range of ions could be released into the electrolyte and impact the corrosion of canister materials. More studies are required to better understand these corrosion interactions, which could advance our understanding and eventually lead to improved models for materials corrosion in long-term post-closure disposal conditions.

\section{METHODS}

Materials

Soda lime silica glass (SLSG) (Fisherbrand ${ }^{\mathrm{TM}}$ 125444) and sodium chloride (NaCl) (crystalline/certified ACS, CAT\# S27150) were purchased from Fisher Scientific and used without further modification or purification. ISG blocks were provided by Pacific Northwest National Laboratory and Savannah River National Laboratory. SS 316 (UNS S31600) was purchased from McMaster-Carr. The compositions of materials used in this study are listed in Table 5. All water used in this study was deionized water (DI water) with a minimum electrical resistivity of $18 \mathrm{M} \Omega \cdot \mathrm{cm}$ (ASTM Type I water). PFA vessels and PTFE coupons and tape were pretreated with $\mathrm{NaOH}$ and $\mathrm{DI}$ water to remove fluoride ions ${ }^{73}$.

\section{Corrosion experiment}

Prior to corrosion, the SLSG $(75 \mathrm{~mm} \times 25 \mathrm{~mm} \times 1 \mathrm{~mm})$ and ISG coupons $(25 \mathrm{~mm} \times 11 \mathrm{~mm} \times 3 \mathrm{~mm})$ were cleaned with ethanol and DI water and dried. The SS sheet was cut into $13 \mathrm{~mm} \times 13 \mathrm{~mm} \times 3 \mathrm{~mm}$ (for SLSG-SS corrosion) or $25 \mathrm{~mm} \times 25 \mathrm{~mm} \times 3 \mathrm{~mm}$ specimens (for ISG-SS corrosion). The alloy G30 and A625 sheets were cut into $13 \mathrm{~mm} \times 13 \mathrm{~mm} \times 3 \mathrm{~mm}$ specimens. All metal samples were abraded to 600 grit with $\mathrm{SiC}$ paper and cleaned with DI water and ethanol and dried for further usage. The metal samples were placed on top of the glass samples to form a crevice between them by gravity. The assemblies were wrapped with PTFE tape to secure them during corrosion, followed by a complete immersion in $0.6 \mathrm{M}$ $\mathrm{NaCl}$ solution or DI water at $90^{\circ} \mathrm{C}$. As control experiments, the glass or metal samples were also pressed against PTFE coupons and corroded under the same conditions. A complete list of experimental groups can be found in Table 1. After 14 or 30 days of static immersion, the assemblies were removed from the solutions. Different materials were separated from each other, cleaned with abundant DI water, air dried, and stored in a desiccator at room temperature for further analysis. The corrosion experiments were replicated at least two times.
Solution analysis

After the corrosion experiment, the solutions were sampled, and the solution composition was analyzed by ICP-OES, (Perkin-Elmer). The equivalent thickness of each element can be calculated using the following equation ${ }^{74}$ :

$$
\operatorname{Eth}(i)=\frac{c(i)}{\frac{S}{V} \times f(i) \times \rho}
$$

where $c(i)$ is the concentration of each species in $\mu \mathrm{g} / \mathrm{mL}, S / V$ is the glass surface area to solution volume ratio in $\mathrm{cm}^{-1}, \mathrm{f}(\mathrm{i})$ is the mass fraction of each element in ISG, and $\rho$ is the density of glass in $\mathrm{g} / \mathrm{cm}^{3}\left(\rho=2.5 \mathrm{~g} / \mathrm{cm}^{3}\right.$ for $I S G^{38}$ ).

\section{X-ray photoelectron spectroscopy}

XPS was employed to characterize the chemical composition of pristine and corroded SLSG and ISG samples. A PHI VersaProbe II spectrometer (Chanhassen) equipped with a monochromatic Al-Ka (1486.6 eV) X-ray source was used. For ISG analysis, the spectra were collected on three different areas: (1) the edge of the contact area of different materials (i.e., crevice mouth area); (2) the center of the contact area, which is the crevice center; (3) the back side of the ISG, which was in contact with the PFA container, as a reference. For each area, the spectra were collected on three random locations. For SLSG analysis, five different locations were examined: (1) the area outside of crevice; (2) the outer band region; (3) the inner band region; (4) the area between inner and outer band; (5) crevice center region. All spectra were calibrated to the adventitious $C 1 \mathrm{~s}$ signal at $284.8 \mathrm{eV}$. All elemental compositions were normalized to the concentration of $\mathrm{Si}$ for better comparison among different samples.

\section{Specular reflection infrared spectroscopy}

Specular reflection infrared (SR-IR) spectroscopy was used to characterize the changes in silicate network through the surface of the SLSG and ISG. The measurement was performed in the mid-infrared range $\left(4000-500 \mathrm{~cm}^{-1}\right)$ using a Bruker Hyperion $3000 \mu-\mathrm{FT}-\mathrm{IR}$ system with a $15 \times$ infrared microscope objective lens (Bruker Optics Inc.). The spectra were collected at a $20^{\circ}$ incidence angle at an average scanning rate of 400 scans per spectrum. The probing area was $100 \mu \mathrm{m} \times 100 \mu \mathrm{m}$, and the spectral resolution was $6 \mathrm{~cm}^{-1}$. The spectrum of a clean gold surface with mirror finish was used as a reference.

\section{Optical microscopy}

The morphologies of altered ISG and SS samples were subjected to analysis by an optical microscopy. A large view of ISG was obtained by manual stitching of multiple micrographs as shown in Fig. 3b-e.

\section{Potentiodynamic polarization}

The effect of ISG leaching solution on SS corrosion was assessed by potentiodynamic polarization. A three-electrode cell was used, including working, counter, and reference electrodes. The SS (abraded to 1200 grit) specimen was loaded into the electrochemical cell and connected as the working electrode. A rubber O-ring was used between the SS and the cell to prevent solution leakage. The SS specimen was mounted into a 
conventional flat cell, which was secured with a rubber O-ring. The O-ring allows an area of $0.785 \mathrm{~cm}^{2}$ to be exposed to the cell solution. A platinum mesh was used as the counter electrode, and a saturated calomel electrode (SCE) served as a reference electrode. Fifty milliliters of testing solution was collected from the leaching solution of ISG(+PTFE DIw $_{\text {) altered }}$ at $90^{\circ} \mathrm{C}$ for 30 days with known solution compositions shown in Table 2. The three-electrode system was immersed in the glass leaching solution. The open circuit potential (OCP) was measured for $30 \mathrm{~min}$ prior to the potentiodynamic polarization. The polarization was started from $50 \mathrm{mV}$ below OCP and proceeded upwards at a scanning rate of $0.167 \mathrm{mV} / \mathrm{min}$. When the current density reached approximately $1 \mathrm{~mA} / \mathrm{cm}^{2}$, the sweeping direction was reversed.

\section{SEM and energy dispersive X-ray spectroscopy}

The corroded ISG and SS samples were characterized by a Thermo Fisher Scientific Apreo FEG SEM equipped with an EDAX Octane Elect EDS System (AMETEK). The altered ISG samples were cross-sectioned to reveal the gel structure. The cross-section was abraded to 1200 grit using SiC paper, cleaned with abundant DI water, and dried for SEM observation. The potentiodynamically polarized SS sample was cleaned with DI water and dried prior to the analysis. The analysis depth (R/nm) of EDS was estimated with Kanaya-Okayama Range equation ${ }^{47}$ :

$R=\frac{2.76 \times 10^{-4} A \cdot E^{5 / 3}}{\rho Z^{8 / 9}}$

where $E_{0}$ is the accelerating voltage of electron beam (V), $A$ is the average atomic weight of the target material $(\mathrm{g} / \mathrm{mol}), Z$ is the average atomic number, and $\rho$ is the density of target material $\left(\mathrm{g} / \mathrm{cm}^{3}\right)$.

\section{DATA AVAILABILITY}

The data that support the findings of this study are available from the corresponding author upon request.

Received: 5 December 2019; Accepted: 12 March 2020;

Published online: 03 April 2020

\section{REFERENCES}

1. Vienna, J. D. Nuclear waste vitrification in the United States: recent developments and future options. Int J. Appl. Glass Sci. 1, 309-321 (2010).

2. IAEA. Status and Trends in Spent Fuel and Radioactive Waste Management (IAEA, 2018).

3. Duquette, D. J., Latanision, R. M., Di Bella, C. A. \& Kirstein, B. E. Corrosion issues related to disposal of high-level nuclear waste in the yucca mountain repository - peer reviewers' perspective. Corrosion 65, 272-280 (2009).

4. Yucca Mountain Repository License Application Safety Analysis Report. (U.S. Department of Energy, Office of Civilian Radioactive Waste Management, Washington, D.C., 2008)

5. Frankel, G. Pitting corrosion of metals a review of the critical factors. J. Electrochem. Soc. 145, 2186-2198 (1998).

6. Kelly, R. G. in Encyclopedia of Electrochemistry (ed Bard, A. J.) 275-307 (2007).

7. Oldfield, J. \& Sutton, W. Crevice corrosion of stainless steels: I. A mathematical model. Br. Corros. J. 13, 13-22 (1978).

8. Oldfield, J. \& Sutton, W. Crevice corrosion of stainless steels: II. Experimental studies. Br. Corros. J. 13, 104-111 (1978).

9. McVay, G. L. \& Buckwalter, C. Q. Effect of iron on waste-glass leaching. J. Am. Ceram. Soc. 66, 170-174 (1983).

10. Burger, E. et al. Impact of iron on nuclear glass alteration in geological repository conditions: A multiscale approach. Appl. Geochem. 31, 159-170 (2013).

11. Werme, L. et al. Chemical corrosion of highly radioactive borosilicate nuclear waste glass under simulated repository conditions. J. Mater. Res. 5, 1130-1146 (1990).

12. Mitsui, S. \& Aoki, R. Effect of a siliceous additive on aqueous alteration of waste glass with engineered barrier materials. J. Nucl. Mater. 298, 184-191 (2001).

13. Schlegel, M. L. et al. Alteration of nuclear glass in contact with iron and claystone at $90^{\circ} \mathrm{C}$ under anoxic conditions: characterization of the alteration products after two years of interaction. Appl. Geochem. 70, 27-42 (2016).

14. Dillmann, P., Gin, S., Neff, D., Gentaz, L. \& Rebiscoul, D. Effect of natural and synthetic iron corrosion products on silicate glass alteration processes. Geochim. Cosmochim. AC 172, 287-305 (2016).
15. Pan, Y.-M., Jain, V. \& Pensado, O. Degradation of high-level waste glass under simulated repository conditions. J. Non-crystalline Solids 319, 74-88 (2003).

16. Guo, X. et al. Self-accelerated corrosion of nuclear waste forms at material interfaces. Nat. Mater. https://doi.org/10.1038/s41563-019-0579-x (2020).

17. Fournier, M., Frugier, P. \& Gin, S. Effect of zeolite formation on borosilicate glass dissolution kinetics. Procedia Earth Planet. Sci. 7, 264-267 (2013).

18. Fournier, M., Gin, S., Frugier, P. \& Mercado-Depierre, S. Contribution of zeoliteseeded experiments to the understanding of resumption of glass alteration. $n p j$ Mater. Degrad. 1, 17 (2017).

19. Gin, S. et al. An international initiative on long-term behavior of high-level nuclear waste glass. Mater. Today 16, 243-248 (2013).

20. Kaspar, T. C. et al. Physical and optical properties of the International Simple Glass. npj Mater. Degrad. 3, 1-15 (2019).

21. Mitton, D. B. \& Yoon, J. H. An overview of corrosion phenomena in SCWO systems for hazardous waste destruction. Zairyo-to-Kankyo 49, 130-137 (2000).

22. Strachan, D. Glass dissolution as a function of $\mathrm{pH}$ and its implications for understanding mechanisms and future experiments. Geochim Cosmochim. AC 219, 111-123 (2017).

23. Inagaki, Y., Kikunaga, T., Idemitsu, K. \& Arima, T. Initial dissolution rate of the international simple glass as a function of $\mathrm{pH}$ and temperature measured using microchannel flow-through test method. Int. J. Appl. Glass Sci. 4, 317-327 (2013).

24. Fournier, M. et al. Effect of $\mathrm{pH}$ on the stability of passivating gel layers formed on International Simple Glass. J. Nucl. Mater. 524, 21-38 (2019).

25. Pederson, L., Buckwalter, C. \& McVay, G. The effects of surface area to solution volume on waste glass leaching. Nucl. Technol. 62, 151-158 (1983).

26. Amma, S.-i. Luo, J., Pantano, C. G. \& Kim, S. H. Specular reflectance (SR) and attenuated total reflectance (ATR) infrared (IR) spectroscopy of transparent flat glass surfaces: a case study for soda lime float glass. J. Non-Crystalline Solids $\mathbf{4 2 8 ,}$ 189-196 (2015).

27. Luo, J. et al. Thermal poling of soda-lime silica glass with nonblocking electrodes-Part 1: Effects of sodium ion migration and water ingress on glass surface structure. J. Am. Ceram. Soc. 99, 1221-1230 (2016).

28. Luo, J., Zhou, Y., Milner, S. T., Pantano, C. G. \& Kim, S. H. Molecular dynamics study of correlations between IR peak position and bond parameters of silica and silicate glasses: effects of temperature and stress. J. Am. Ceram. Soc. 101, 178-188 (2018).

29. Luo, J., Zhou, Y., Pantano, C. G. \& Kim, S. H. Correlation between IR peak position and bond parameter of silica glass: molecular dynamics study on fictive temperature (cooling rate) effect. J. Am. Ceram. Soc. 101, 5419-5427 (2018).

30. Morinaga, K., Suginohara, Y. \& Yanagase, Y. Infrared absorption spectra of silicate glasses containing $\mathrm{Fe}_{2} \mathrm{O}_{3}$. J. Jpn. Inst. Met. 40, 775-780 (1976).

31. Iordanova, R., Dimitriev, Y., Dimitrov, V., Kassabov, S. \& Klissurski, D. Glass formation and structure in the $\mathrm{V}_{2} \mathrm{O}_{5} \cdot \mathrm{Bi}_{2} \mathrm{O}_{3} \cdot \mathrm{Fe}_{2} \mathrm{O}_{3}$ glasses. J. Non-Crystalline Solids 204, 141-150 (1996).

32. Campbell, J. Vibrational frequencies of the chromium-oxygen bond and the oxidation state of chromium. Spectrochimica Acta 21, 851-852 (1965).

33. Frankel, G. S. et al. A comparative review of the aqueous corrosion of glasses, crystalline ceramics, and metals. npj Mater. Degrad. 2, 15 (2018).

34. Kaspar, T. C., Reiser, J. T., Ryan, J. V. \& Wall, N. A. Non-destructive characterization of corroded glass surfaces by spectroscopic ellipsometry. J. Non-Crystalline Solids 481, 260-266 (2018).

35. Prassas, M., Phalippou, J. \& Zarzycki, J. Synthesis of monolithic silica gels by hypercritical solvent evacuation. J. Mater. Sci. 19, 1656-1665 (1984).

36. Chave, T., Frugier, P., Gin, S. \& Ayral, A. Glass-water interphase reactivity with calcium rich solutions. Geochim Cosmochim. AC 75, 4125-4139 (2011).

37. Rajmohan, N., Frugier, P. \& Gin, S. Composition effects on synthetic glass alteration mechanisms: Part 1. Experiments. Chem. Geol. 279, 106-119 (2010).

38. Gin, S. et al. The fate of silicon during glass corrosion under alkaline conditions: a mechanistic and kinetic study with the International Simple Glass. Geochim Cosmochim. AC 151, 68-85 (2015).

39. Cailleteau, C. et al. Insight into silicate-glass corrosion mechanisms. Nat. Mater. 7, 978 (2008).

40. Jollivet, P. et al. Zirconium local environment in simplified nuclear glasses altered in basic, neutral or acidic conditions: evidence of a double-layered gel. J. NonCrystalline Solids 503, 268-278 (2019).

41. Rydberg, J. Groundwater Chemistry of a Nuclear Waste Reposoitory in Granite Bedrock. (Lawrence Livermore National Lab., CA, 1981).

42. Kerrisk, J. F. Groundwater Chemistry at Yucca Mountain, Nevada, and Vicinity. (Los Alamos National Lab., 1987).

43. Hem, J. D. Study and Interpretation of the Chemical Characteristics of Natural Water. Vol. 2254 (Department of the Interior, US Geological Survey, 1985).

44. Beverskog, B. \& Puigdomenech, I. Revised Pourbaix diagrams for iron at 25-300 C. Corros. Sci. 38, 2121-2135 (1996). 
45. Trotignon, L., Petit, J.-C., Della Mea, G. \& Dran, J.-C. The compared aqueous corrosion of four simple borosilicate glasses: influence of $\mathrm{Al}, \mathrm{Ca}$ and $\mathrm{Fe}$ on the formation and nature of secondary phases. J. Nucl. Mater. 190, 228-246 (1992).

46. Jollivet, P., Gin, S. \& Schumacher, S. Forward dissolution rate of silicate glasses of nuclear interest in clay-equilibrated groundwater. Chem. Geol. 330, 207-217 (2012).

47. Kanaya, K. \& Okayama, S. Penetration and energy-loss theory of electrons in solid targets. J. Phys. D.-Appl. Phys. 5, 43-58 (1972).

48. Gin, S. et al. Dynamics of self-reorganization explains passivation of silicate glasses. Nat. Commun. 9, 2169 (2018).

49. Parsons, J. \& Milberg, M. Vibrational spectra of vitreous $\mathrm{B}_{2} \mathrm{O}_{3} . \mathrm{xH}_{2} \mathrm{O}$. J. Am. Ceram. Soc. 43, 326-330 (1960).

50. Luo, J., Smith, N. J., Pantano, C. G. \& Kim, S. H. Complex refractive index of silica, silicate, borosilicate, and boroaluminosilicate glasses-Analysis of glass network vibration modes with specular-reflection IR spectroscopy. J. Non-Crystalline Solids 494, 94-103 (2018)

51. Wilson, M., Madden, P. A., Hemmati, M. \& Angell, C. A. Polarization effects, network dynamics, and the infrared spectrum of amorphous $\mathrm{SiO}_{2}$. Phys. Rev. Lett. 77, 4023 (1996).

52. Kim, M., Jang, S., Woo, S., Kim, J. \& Kim, Y. Corrosion resistance of ferritic stainless steel in exhaust condensed water containing aluminum cations. Corrosion 71, 285-291 (2014)

53. Liu, C., Khullar, P. \& Kelly, R. G. Acceleration of the cathodic kinetics on aluminum alloys by aluminum ions. J. Electrochem. Soc. 166, C153-C161 (2019).

54. Miyake, T. \& Rolandi, M. Grotthuss mechanisms: from proton transport in proton wires to bioprotonic devices. J. Phys.: Condens. Matter 28, 023001 (2015).

55. Li, M. C., Zeng, C., Lin, H. \& Cao, C. Electrochemical corrosion behaviour of type 316 stainless steel in acid media containing fluoride ions. Br. Corros. J. 36, 179-183 (2001)

56. ASTM C1285-14. Standard test methods for determining chemical durability of nuclear, hazardous, and mixed waste glasses and multiphase glass ceramics: the product consistency test (PCT). (2014).

57. Long, J. C. \& Ewing, R. C. Yucca Mountain: Earth-science issues at a geologic repository for high-level nuclear waste. Annu. Rev. Earth Planet. Sci. 32, 363-401 (2004).

58. Johnson, L., Tait, J., Shoesmith, D., Crosthwaite, J. \& Gray, M. The disposal of Canada's nuclear fuel waste: engineered barriers alternatives. (Atomic Energy of Canada Limited, 1994).

59. Shoesmith, D. Assessing the corrosion performance of high-level nuclear waste containers. Corrosion 62, 703-722 (2006).

60. Le Caër, S. Water radiolysis: influence of oxide surfaces on $\mathrm{H} 2$ production under ionizing radiation. Water 3, 235-253 (2011).

61. DOE. Site Characterization Plan, Yucca Mountain Site, Nevada Research and Development Area, Nevada (1988).

62. Bates, J., Bradley, J., Teetsov, A., Bradley, C. \& Ten Brink, M. B. Colloid formation during waste form reaction: implications for nuclear waste disposal. Science $\mathbf{2 5 6}$ 649-651 (1992).

63. Stenhouse, M., Apted, M. \& Zhou, W. EPRI Review of Geologic Disposal for Used Fuel and High Level Radioactive Waste: Volume III-Review of National Repository Programs (Electric Power Research Institute, Palo Alto, CA, 2010).

64. DOE, U. Site Characterization Plan, Yucca Mountain Site, Nevada Research and Development Area. (DOE/RW-0199. Washington, DC: OCRWM, 1985).

65. Angst, U., Elsener, B., Larsen, C. K. \& Vennesland, Ø. Chloride induced reinforcement corrosion: rate limiting step of early pitting corrosion. Electrochim. Acta 56, 5877-5889 (2011).

66. Mesmer, R. \& Baes, C. The hydrolysis of cations. Ed. Wiley, EUA (1976).

67. Frankel, G. S., Li, T. \& Scully, J. R. Perspective-localized corrosion: passive film breakdown vs pit growth stability. J. Electrochem. Soc. 164, C180-C181 (2017).

68. Chen, J.-R. et al. Studies on carbon steel corrosion in molybdate and silicate solutions as corrosion inhibitors. Surf. Sci. 247, 352-359 (1991).

69. Salasi, M., Shahrabi, T., Roayaei, E. \& Aliofkhazraei, M. The electrochemical behaviour of environment-friendly inhibitors of silicate and phosphonate in corrosion control of carbon steel in soft water media. Mater. Chem. Phys. 104, 183-190 (2007)
70. Gao, H. et al. Study of the corrosion inhibition effect of sodium silicate on AZ91D magnesium alloy. Corros. Sci. 53, 1401-1407 (2011).

71. Aramaki, K. The inhibition effects of chromate-free, anion inhibitors on corrosion of zinc in aerated $0.5 \mathrm{M} \mathrm{NaCl}$. Corros. Sci. 43, 591-604 (2001).

72. Lopez-Garrity, O. \& Frankel, G. Corrosion inhibition of AA2024-T3 by sodium silicate. Electrochim. Acta 130, 9-21 (2014).

73. Jantzen, C. M. \& Bibler, N. E. in Environmental Issues and Waste Management Technologies in the Ceramic and Nuclear Industries XI: Proceedings of the 107th Annual Meeting of The American Ceramic Society, Baltimore, Maryland, USA 2005, Ceramic Transactions. 141 (Wiley-American Ceramic Society, 2005).

74. Gin, S. et al. Origin and consequences of silicate glass passivation by surface layers. Nat. Commun. 6, 6360 (2015).

75. Youmans, H. L. Measurement of pH of distilled water. J. Chem. Educ. 49, 429 (1972).

\section{ACKNOWLEDGEMENTS}

This work was supported as part of the Center for Performance and Design of Nuclear Waste Forms and Containers, an Energy Frontier Research Center funded by the U.S Department of Energy, Office of Science, Basic Energy Sciences under Award \# DESC0016584. The authors would like to thank Dr. Charles Crawford from Savannah River National Laboratory for supplying the International Simple Glass. The authors would also like to thank Yutichai Mueanngern and Dr. Yehia Khalifa from Ohio State University for their assistance with XPS measurement.

\section{AUTHOR CONTRIBUTIONS}

X.G., S.G., S.H.K., J.D.V., J.V.R. and G.S.F designed the research; X.G., H.L., D.N., J.L., S.S. and C.M. performed the research; X.G., S.G., H.L., D.N., J.L. and S.H.K. analyzed the data All authors contributed to the editing of the paper, and approval of the content in its current form.

\section{COMPETING INTERESTS}

The authors declare no competing interests.

\section{ADDITIONAL INFORMATION}

Correspondence and requests for materials should be addressed to X.G.

Reprints and permission information is available at http://www.nature.com/ reprints

Publisher's note Springer Nature remains neutral with regard to jurisdictional claims in published maps and institutional affiliations.

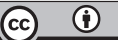

Open Access This article is licensed under a Creative Commons Attribution 4.0 International License, which permits use, sharing, adaptation, distribution and reproduction in any medium or format, as long as you give appropriate credit to the original author(s) and the source, provide a link to the Creative Commons license, and indicate if changes were made. The images or other third party material in this article are included in the article's Creative Commons license, unless indicated otherwise in a credit line to the material. If material is not included in the article's Creative Commons license and your intended use is not permitted by statutory regulation or exceeds the permitted use, you will need to obtain permission directly from the copyright holder. To view a copy of this license, visit http://creativecommons. org/licenses/by/4.0/.

(c) The Author(s) 2020 